\title{
Diagnostic Species Diversity Pattern Can Provide Key Information on Vegetation Change: An Insight into High Mountain Habitats in Central Apennines
}

\author{
Marco Varricchione ${ }^{1,2}\left(\right.$, Valter Di Cecco ${ }^{3} \oplus$, Lucia A. Santoianni ${ }^{2}$, Angela Stanisci ${ }^{1,2}{ }^{\oplus}$, Mirko Di Febbraro ${ }^{2}($, \\ Luciano Di Martino ${ }^{3}(\mathbb{D})$ and Maria Laura Carranza ${ }^{1,2, *(D)}$ \\ 1 EnvixLab, Dipartimento di Bioscienze e Territorio, Università degli Studi del Molise, C. da Fonte Lappone, \\ 86090 Pesche, IS, Italy; m.varricchione@studenti.unimol.it (M.V.); stanisci@unimol.it (A.S.) \\ 2 EnvixLab, Dipartimento di Bioscienze e Territorio, Università degli Studi del Molise, Via Duca degli Abruzzi, \\ 67, 86039 Termoli, CB, Italy; 1.santoianni@studenti.unimol.it (L.A.S.); mirko.difebbraro@unimol.it (M.D.F.) \\ 3 Maiella Seed Bank, Maiella National Park, Loc. Colle Madonna, 66010 Lama dei Peligni, CH, Italy; \\ valter.dicecco@parcomajella.it (V.D.C.); luciano.dimartino@parcomajella.it (L.D.M.) \\ * Correspondence: carranza@unimol.it
}

check for updates

Citation: Varricchione, M.; Di Cecco, V.; Santoianni, L.A.; Stanisci, A.; Di Febbraro, M.; Di Martino, L.; Carranza, M.L. Diagnostic Species Diversity Pattern Can Provide Key Information on Vegetation Change: An Insight into High Mountain Habitats in Central Apennines. J. Zool. Bot. Gard. 2021, 2, 453-472. https:// doi.org/10.3390/jzbg2030033

Academic Editor: Gianluigi Bacchetta

Received: 27 July 2021

Accepted: 30 August 2021

Published: 3 September 2021

Publisher's Note: MDPI stays neutral with regard to jurisdictional claims in published maps and institutional affiliations.

Copyright: (C) 2021 by the authors Licensee MDPI, Basel, Switzerland. This article is an open access article distributed under the terms and conditions of the Creative Commons Attribution (CC BY) license (https:// creativecommons.org/licenses/by/ $4.0 /)$.

\begin{abstract}
High mountain ecosystems are hotspots of biodiversity that are highly vulnerable to climate warming and land use change. In Europe, high mountain habitats are included in the EC Directive 92/43/EEC (Habitats Directive) and the identification of practices facilitating effective monitoring is crucial for meeting HD goals. We analyzed the temporal changes in species composition and diversity on high mountain EU habitats and explored if the subgroup of diagnostic species was able to summarize the comprehensive information on plant community variations. We performed a re-visitation study, using a set of 30 georeferenced historical plots newly collected after 20 years on two EU habitats (Galium magellense community growing on screes (8120 EU) and Trifolium thalii community of snowbeds (6170 EU)) in the Maiella National Park (MNP), which is one of the most threatened Mediterranean mountains in Europe. The presence of several endangered species and the availability of a botanical garden, a seed bank, and a nursery, make the MNP an excellent training ground to explore in situ and ex situ conservation strategies. We compared overall and diagnostic species richness patterns over time by rarefaction curves and described the singular aspects of species diversity (e.g., richness, Shannon index, Simpson index, and Berger-Parker index), by Rènyi's diversity profiles. Diversity values consistently varied over time and across EU habitat types, with increasing values on scree communities and decreasing values on snowbeds. These changes could be associated with both land use change, through the increase of grazing pressure of Apennine chamois (Rupicapra pyrenaica ornata), which determined a rise of nitrophilous species in the scree community, and an increase of grasses at the expense of forbs in snowbeds, and to climate change, which promoted a general expansion of thermophilous species. Despite the two opposite, ongoing processes on the two plant communities studied, our results evidenced that diagnostic species and overall species followed the same trend of variation, demonstrating the potential of diagnostics for EU habitat monitoring. Our observations suggested that the re-visitation of historical plots and the implementation of frequent monitoring campaigns on diagnostic species can provide important data on species abundance and distribution patterns in these vulnerable ecosystems, supporting optimized in situ and ex situ conservation actions.
\end{abstract}

Keywords: ecological monitoring; EU Habitats Directive; rarefaction curves; Rènyi's diversity profiles; re-visitation study; vegetation database

\section{Introduction}

High mountain ecosystems are hotspots of biodiversity [1,2], as they host a high number of plant species with a large number of endemic and rare taxa [3-7], most of 
which are vulnerable to climate warming [8,9]. In Europe, they contain ca. $20 \%$ of all the native flora of the continent [10]. Due to their peculiar environmental characteristics, these ecosystems are very sensitive and threatened by direct and indirect human impacts, such as climate and land use change (e.g., rising temperatures, changes in precipitation patterns, and grazing pressure), which affect biodiversity and ecosystem functioning [11-13].

Encompassing global change, severe alterations in plant diversity have been observed based on short-term $[14,15]$ and on long-term vegetation analysis [16-18]. For instance, a significant thermophilization of high mountain plant communities has been observed due to the immigration of thermophilous plants from lower altitudinal belts along with a decrease in the number of cryophilous species [1,4,13,19-25]. Shrubs expansion, local herbaceous species extinctions, and consistent changes in the ecology and structure of high mountain communities were also described $[12,18,26]$.

In response to the ongoing biodiversity loss, several high mountain habitats are included in the European Habitat Directive 43/92/EEC (hereafter HD), a legal instrument to protect them and ensure their resilience to global changes [27-29]. According to the $\mathrm{HD}$, the preservation, continuous monitoring, and reporting of high mountain ecosystems' status are a priority at both the national and European level [30,31]. In fact, the identification of practices facilitating effective monitoring is crucial for meeting HD goals [30].

The plethora of approaches proposed for monitoring high mountain vegetation can be schematically organized in two main categories: the first one is based on data collected on permanent plots (e.g., [25,32,33]), and the second one is supported by the re-visitation of historical vegetation plots (e.g., [20,21,34-36]). The most reliable monitoring method is based on multi-temporal data collection on a fixed set of permanent plots [4,32]. An excellent example of a sound protocol for monitoring high mountain ecosystem is offered by the GLORIA project (Global Observation Research Initiative in Alpine Environments; [37]), which operates a world-wide observation network with standardized permanent plot sites aimed at assessing climate change impacts on alpine vegetation and biodiversity [38]. The International Long Term Ecological Network [39] includes several mountain sites for which long time-series ecological data are available. However, permanent observation areas are not easy to implement and a staff dedicated to periodical surveys is hardly assured. Accordingly, this approach can be carried out over a limited set of geographical areas [40]. Furthermore, data on permanent observation areas are not always open access [41], with the temporal coverage mostly including short-term periods over the last decades [42].

Another increasingly used approach for describing vegetation changes over time is given by re-visitation studies, which entails re-sampling historical vegetation plots surveyed by other authors, in the same area $[13,17,18,34,36]$. A considerable number of historical plots are stored in vegetation geodatabases (e.g., European Vegetation Archive; http:/ / euroveg.org/eva-database; accessed date 7 April 2021 [43]), which make them easy to share and use. In some cases, the re-survey approach represents the only available tool for monitoring vegetation changes [44,45].

Although the need for ecosystem monitoring is clear, the regular assessment of biodiversity in high mountain ecosystems is difficult to undertake [46], especially if the overall species richness for each habitat must be recorded [47]. The economic restrictions in many countries hinder the implementation of monitoring plans supported by large-scale fieldwork [48]. Furthermore, collecting extensive data on the overall species pool could be hampered by the time and the effort required to reach some remote monitoring areas $[48,49]$. As a result, such sampling limitations restrict the implementation of sound monitoring schemes that are essential for the better understanding and modelling of high mountain biodiversity over time [50].

Some research, carried out to identify cost-effective indicators of the conservation status and function of natural and semi-natural habitats, has suggested the usefulness of diagnostic species for describing different ecosystems, such as forests (e.g., [51,52]), grasslands [53], and coastal dunes [54,55]. Diagnostic species (as defined by HD) are those taxa with a major role in determining plant community structure, function, and 
conditions [54,56]. Diagnostic species can be considered "focal taxa", which help to assure the functionality of the entire habitat and are particularly sensitive to environmental changes [13,57]. For instance, diagnostic species indicated in the HD for high mountain habitats may play a major role in determining the structure and functioning of these systems as they could regulate the supply of resources for other species [58-60]. Moreover, their alteration may promote significant changes in the local environment, driving a spatial shift, modification, or subsistence of the surrounding habitats [16,18].

Although the response of high mountain plant species or habitats of European interest to environmental threats have been repeatedly documented (e.g., $[1,4,25,38]$ ), the analysis of diagnostic species diversity patterns with respect to the entire pool of species still requires further attention.

The present work set out to explore the temporal changes in species composition and diversity of two high mountain vegetation types that are representative and widespread in the Italian Apennine's alpine belt (e.g., Galium magellense community growing on screes (8120 EU Habitat) and Trifolium thalii community of snowbeds (6170 EU Habitat)). We explored whether diagnostic species were able to summarize the comprehensive information on plant community changes by comparing the diversity patterns of diagnostic species assemblages with those of overall species on vegetation plots revisited after 20 years. We specifically analyzed these two habitats of conservation concern (sensu 92/43/EEC) in the Maiella National Park to address the following questions: (i) how have the plant diversity patterns changed during the last 20 years? (ii) does the diversity pattern of diagnostic species and of the overall species pool vary in a similar way?

By adopting the widely used EU Habitat standard system of vegetation classification, we were able to supply specific habitat insights that were useful for supporting monitoring strategies at the European scale and for contributing to the definition of conservation and management priorities.

\section{Materials and Methods}

\subsection{Study Area}

The study area included the highest sector of the Maiella National Park (about $24.5 \mathrm{~km}^{2}$ over $2300 \mathrm{~m}$ a.s.1.), which is one of the most important limestone mountain groups in the Central Apennines (Figure 1). The Park consists mainly of carbonate mountains, separated by valleys and karst high plateaus, with a broad altitudinal range (130-2793 $\mathrm{m}$ a.s.1.). The Maiella massif has more than 60 peaks, with half of them rising above $2000 \mathrm{~m}$, and includes the second highest peak in the Apennines, i.e., Mount Amaro (2793 m a.s.1.). The mountain chain, which developed with a north-south alignment for about $30 \mathrm{~km} \mathrm{[61,62],} \mathrm{is} \mathrm{formed} \mathrm{by}$ peaks with gentle summit profiles and extensive summit areas, bordered by steep slopes and crossed by deep valleys of glacial origin [63].

The Park territories are part of the Natura 2000 network. The boundaries coincide with a Special Protection Area (SPA) for the conservation of wild birds (established by the Birds Directive 79/409/EEC). Furthermore, four Special Areas of Conservation (SAC) established by Habitat Directive 92/43/EEC [64] occur within the Park.

The Park is an example where ex situ and in situ conservation strategies (e.g., endemic, rare, and endangered species) are implemented in a complementary way. It is extremely rich in plant vascular species, with its flora listing a high number of specific and subspecific taxa, for a total of 2286 [65], and a sizeable group of southern European orophytes and Mediterranean montane species [5], thus representing a true biodiversity hotspot [66]. The natural biodiversity is supported by shelters offered by geography and the natural environment, and the park authority assures a set of facilities required to implement ex situ conservation strategies, such as a botanical garden, a seed bank, a nursery, and a network of "guardian farmers" [64].

From a bioclimatic point of view, the study area is included in the alpine biogeographical region [67] and the climate corresponds to the subalpine-alpine humid type as far as the lower summit is concerned, whereas the other summits belong to the alpine 
humid type [68]. The analysis of temporal climate series in the higher Apennine massifs showed a significant increase in the last 50 years in terms of annual temperatures $\left(+1.7^{\circ} \mathrm{C}\right)$, amounting to $0.26^{\circ} \mathrm{C}$ per decade [17]. Moreover, during the last century, the spring and winter minimum temperatures increased by $2.87^{\circ} \mathrm{C}$ and $4.38^{\circ} \mathrm{C}$, respectively [69]. Summer minimum temperatures have increased $\left(3.17^{\circ} \mathrm{C}\right)$, while summer maximum temperatures have decreased $\left(-2.69^{\circ} \mathrm{C}\right)$ [18]. Furthermore, the summer (June-August) mean soil temperatures of the Maiella summits have increased by $1{ }^{\circ} \mathrm{C}$ in the last 20 years (see details on general trends on [37]; for local soli temperatures, see Appendix A).

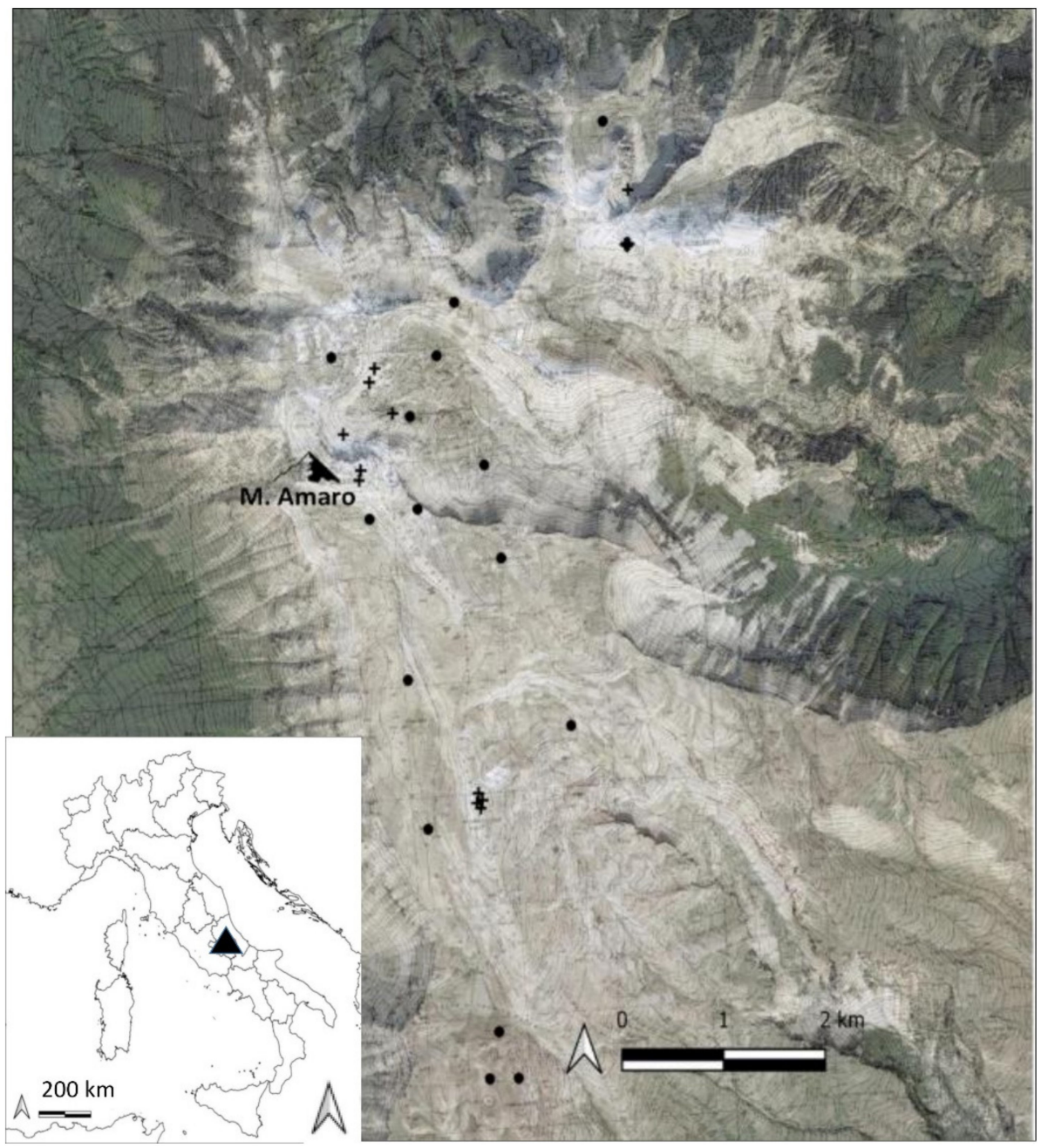

Figure 1. Study area (Maiella National Park in Central Italy) along with the distribution of plots relative to screes plant communities (+) and snowbed plant communities $(\bullet)$.

Traditional land use in the Maiella National Park was shaped by human practices, such as pastoralism, and has gradually changed over the last half century. Natural subalpine and alpine communities are changing due to the abandonment of traditional land use and the tree-line rise towards upper grasslands $[13,70]$, as well as to the recent reintroduction of the Apennine chamois (Rupicapra pyrenaica ornata Neumann, 1899; [71,72]). The population of the Apennine chamois were reintroduced in the years 1991-1992 and 2000, and has expanded [73], reaching 1300 individuals by the year 2019 (http: //www.camoscioappenninico.it/; (accessed on 7 April 2021).

We focused on the Galium magellense community, growing on screes, and the Trifolium thalii community of snowbeds. The former is included in the 8120 EU Habitat (calcareous and calcshist screes of the montane to alpine levels-Thlaspietea rotundifolii) and occupies the steep slopes with incoherent substrate and abundant limestone debris, occur- 
ring at mean altitudes of $2660 \mathrm{~m}$ a.s.l. Vegetation in such limiting environmental conditions, where soils are undeveloped, dry, and poor in organic matter, is sparsely distributed and intermingled with bare surfaces [5].

The snowbed plant community is included in the 6170 EU Habitat (alpine and subalpine calcareous grasslands; [74,75]) and grows on small micro-dolines occurring at a mean altitude of $2450 \mathrm{~m}$ a.s.l., where the snow cover remains for long periods (at least 8 months). Snowbed soils are wet, well-developed, and rich in organic matter, and vegetation is characterized by close formations dominated by perennial grass and forb species [5].

\subsection{Vegetation Data}

For this study, we extracted, from the VIOLA database [76,77], a set of 30 georeferenced vegetation plots ( 15 for the scree plant community and 15 the for snowbed plant community) sampled in the years 2001 and 2003 (hereafter T1) in Maiella National Park and we resampled them in the years 2015 and 2020 (here after T2). In detail, these data include eight permanent plots from the GLORIA project (Global Observation Research Initiative in Alpine Environments; [37]) collected during 2001 and re-sampled in 2015, and 22 phytosociological relevés sampled in 2003 [78] and resampled in 2020.

For each georeferenced vegetation plot of $16 \mathrm{~m}^{2}(4 \times 4 \mathrm{~m})$, all plant species and their cover/abundance along the Braun-Blanquet scale $[79,80]$ were registered.

The nomenclature follows the updated checklists of the vascular flora native to Italy [81]. For each taxon, the accepted name and the Italian endemic status are reported. Diagnostic species of the analyzed high mountain plant communities (Table 1) were identified following the "Vegetation Prodrome" [82], which conforms to the Interpretation Manual of European Union Habitats [75] and the Italian Interpretation Manual of the 92/43/EEC Directive Habitats [74]. These diagnostic plant species are locally common, but highly specialized to live on mountain summits and, therefore, are restricted to this environment $[74,83]$. In order to depict the main plant strategies of the analyzed communities, we also considered the life growth for each species $[84,85]$ (Table 1$)$.

Table 1. Diagnostic species of the compared high mountain plant communities (conforming the Vegetation Prodrome of Italy [82] and the Italian Interpretation Manual of the 92/43/EEC Directive Habitats [74]) along with their relative life growth (LGr: sensu [85]). CH pulv: pulvinate chamaephytes; $\mathrm{CH}$ suffr: suffruticose chamaeophytes; G rhiz: rhizomatose geophyte; $\mathrm{H}$ caesp: caespitose cemicryptophytes; $\mathrm{H}$ ros: hemicryptophytes with rosette; $\mathrm{H}$ scap: scapose hemicryptophytes; and T scap: scapose therophytes.

Galium magellense Community (Screes) TAXON

\section{LGr}

$\begin{array}{ll}\text { H scap } & \text { Crepis aurea subsp. glabrescens } \\ \text { CH suffr } & \text { Draba aizoides subsp. aizoides } \\ \text { H scap } & \text { Helianthemum oelandicum subsp. alpestre } \\ \text { H scap } & \text { Luzula spicata subsp. bulgarica } \\ \text { CH suffr } & \text { Phyteuma orbiculare } \\ \text { G rhiz } & \text { Plantago atrata subsp. atrata } \\ \text { H scap } & \text { * Polygala alpestris subsp. angelisii } \\ \text { G rhiz } & \text { Pulsatilla alpina subsp. millefoliata } \\ \text { H scap } & \text { *Ranunculus pollinensis } \\ \text { G rhiz } & \text { Sagina glabra } \\ \text { H caesp } & \text { *araxacum apenninum } \\ \text { H scap } & \\ \text { CH suffr } & \\ \text { H scap } & \\ \text { G rhiz } & \\ \text { CH pulv } & \\ \text { H ros } & \\ \text { T scap } & \\ \text { H scap } & \end{array}$

Trifolium thalii Community (Snowbeds) LGr

$\mathrm{H}$ ros $\mathrm{H}$ ros $\mathrm{CH}$ suffr H caesp H scap H ros H scap H scap H scap H caesp $\mathrm{H}$ ros

Leucopoa dimorpha

* Linaria purpurea

* Noccaea stylosa

Papaver alpinum subsp. alpinum

Ranunculus brevifolius

* Saxifraga oppositifolia subsp. speciosa

* Scorzoneroides montana subsp. breviscapa

Sedum atratum

* Viola magellensis 


\subsection{Data Analysis}

For each community, we compared the $\beta$-diversity (i.e., diversity between plots) of the 30 plots hosting the comprehensive sampled pool with the $\beta$-diversity of the same plots after having set non-diagnostic species as absent in the site-species matrix. The $\beta$-diversity values of these two groups of plots were expressed as multivariate variances computed as the distance between each group's items (i.e., plots) and each group's centroid by reducing the original Bray-Curtis distances to principal coordinates [86]. Differences in multivariate variances were assessed through the multivariate analogue to Levene's test of the equality of variances, evaluating their significance with a permutation test with 999 repetitions [87].

Subsequently, we described overall and diagnostic species diversity patterns over time using rarefaction curves, a widely used method for estimating standardized species richness [88], which proved efficient to describe high mountain vegetation patterns [5]. We compared patterns of overall species richness and diagnostic species richness for the considered time steps (T1 and T2), calculating plot-based rarefaction curves [88,89]. In order to explore the singular aspects of species diversity (e.g., richness, equitability, and dominance) of all species and of the subgroup of diagnostic species, we realized Rènyi's diversity profiles for cover values on both dataset time steps (T1 and T2) $[90,91]$ and calculated Shannon and Simpson diversity indices.

All analyses were performed in R [92], using vegan [87], Rarefy [93] and BiodiversityR [94] packages, and PAST (paleontological statistics software for education and data analysis [95]).

Based on the observation that traditional diversity indices measure different aspects of the partition of abundance between species, [90] proposed a unifying formulation of diversity, according to Renyi's generalized entropy measure, which represents the starting point for a continuum of possible diversity measures. In fact, for a distribution function characterized by its proportional abundance $p i=(p 1, p 2, \ldots, p N)$, [96] extended the concept of Shannon's information (entropy) defining a generalized entropy of order $\alpha$ as:

$$
H_{\alpha}=\frac{1}{1-\alpha} \log \sum_{i=1}^{N} p_{i}^{\alpha}
$$

where $0 \geq \alpha \geq 1$ and pi denote the relative abundance of the ith element in a system $(i=1$, $2, \ldots, \mathrm{N})$, such that $0 \leq p_{i} \leq 1$ and $\sum_{i=1}^{N} p_{i}=1$.

Rènyi's formula summarizes a sequence of diversity indices that become increasingly dependent on the commonest element types for increasing values of the parameter $\alpha$. The parameter $\alpha$ represents a sort of complex nonlinear measure of the weight that the index $\mathrm{H} \alpha$ attributes to species richness and dominance concentration for a specific community. Notice that several popular diversity indices consist of particular cases of $\mathrm{H} \alpha$ [90]. For example, for $\alpha=0, \mathrm{H} 0=\log \mathrm{N}$, where $\mathrm{N}$ is the total number of species; for $\alpha=1, \mathrm{H} 1$ $=\operatorname{expH}$, where $\mathrm{H}$ is Shannon's index $\sum_{i=1}^{N} p_{i}$ [97]; for $\alpha=2, \mathrm{H} 2=\log 1 / \mathrm{D}$, where $\mathrm{D}$ is Simpson's index $\sum_{i=1}^{N} p_{i}^{2}$ [98], and for $\alpha=\infty, \mathrm{H} \infty=\log 1 / \mathrm{d}=\log 1 / \mathrm{pmax}$, where $\mathrm{d}$ is the Berger-Parker index [99] and pmax is the proportional abundance of the most abundant species in the community.

For a given community, $\mathrm{H} \alpha$ is a decreasing function of $\alpha$. Thus, changing $\alpha$ allows for vector representation of community structure that can be plotted by a diversity profile of $\mathrm{H} \alpha$ versus $\alpha[100]$.

\section{Results}

The recorded species list included 145 vascular plant species and subspecies, 70 for the Galium magellense community (screes) and 75 for the Trifolium thalii community (snowbeds). Thirty of the total species registered are diagnostic (about 21\%), specifically 19 for screes $(27 \%)$ and 11 for snowbeds (15\%) (Table 2). 
Table 2. Basic floristic data for both plant communities in the two time intervals (T1: 2001-2003; T2: 2015-2020). M: number of sampled plots; $S_{\text {all species: }}$ number of all species recorded; and $S_{\text {diagnostics }}$ number of diagnostic species recorded.

\begin{tabular}{ccccc}
\hline & Galium magellense & Community & \multicolumn{2}{c}{ Trifolium thalii } \\
& T1 & T2 & T1 & T2 \\
\hline $\mathrm{M}$ & 15 & 15 & 15 & 15 \\
$\mathrm{~S}_{\text {all species }}$ & 51 & 67 & 70 & 60 \\
$\mathrm{~S}_{\text {diagnostics }}$ & 15 & 19 & 11 & 9 \\
\hline
\end{tabular}

For both communities, multivariate Levene's test for homogeneity of a group's variances did not report significant differences between $\beta$-Diversity values of plots with the overall species pool and those with only diagnostic species (e.g., screes $p$ value $=0.960$; and dolines $p$ value $=0.126$; Figure 2).
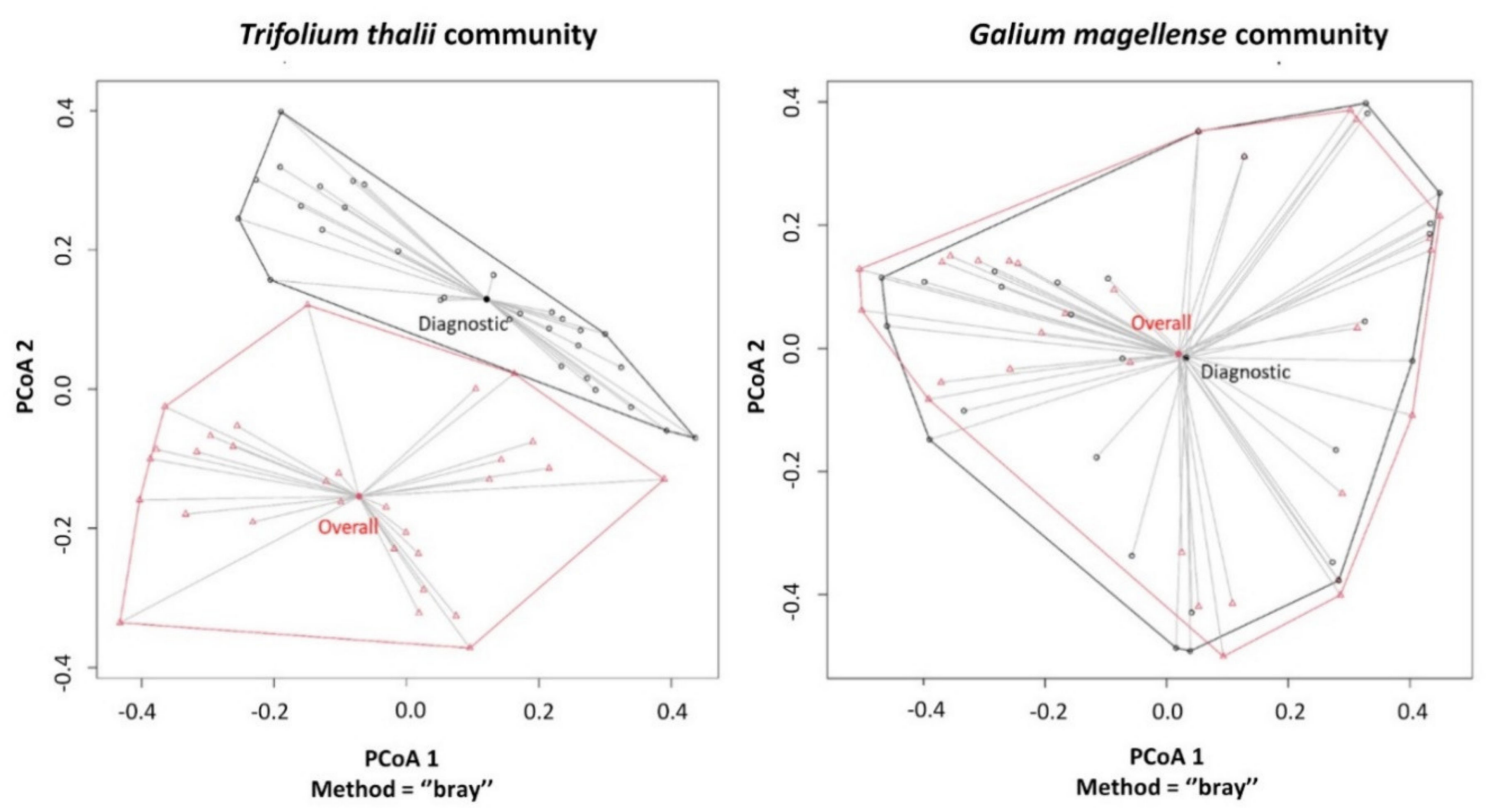

Figure 2. $\beta$-Diversity analysis for Trifolium thalii community and Galium magellense community performed on cover values for overall and diagnostic species. Principal coordinate plots report the two groups of sites within the minimum convex polygons, along with their multivariate centroids. Multivariate Levene's test showed no significant differences between multivariate variances of the two groups of plots in both plant communities.

Rarefaction curves and the Rènyi profiles in T1 and T2 for the overall species pool and for the diagnostic species showed different temporal changes in the two studied plant communities (Figures 3 and 4). Rarefaction curves on the Galium magellense community showed a temporal increase in the overall species richness, growing from 51 to 67 (Table 3) as well as on the diagnostic species, which increased from 15 to 19. Similarly, the Renyi's diversity profiles showed consistent increases of diversity values over time for both overall and diagnostic species. Shannon and Simpson total values increased from 3.649 to 3.916 and from 0.9676 to 0.9743 respectively (Table 3), while Shannon and Simpson diagnostic values increased from 2.404 to 2.709 and from 0.8885 to 0.9187 , respectively. Rarefaction curves on the Trifolium thalii community revealed a temporal decrease in the overall species richness, which declined from 70 to 61 (Table 3), as well as on the diagnostic species, which decreased from 11 to 9 . Likewise, the Rènyi's diversity profiles showed consistent decreases over time of diversity values for both overall and diagnostic species. Shannon and Simpson total values decreased from 3.932 to 3.814 and from 0.976 to 0.9739 , respectively (Table 3), while Shannon and Simpson diagnostic values decreased from 2.109 to 1.921 and from 0.8567 to 0.826 respectively. 

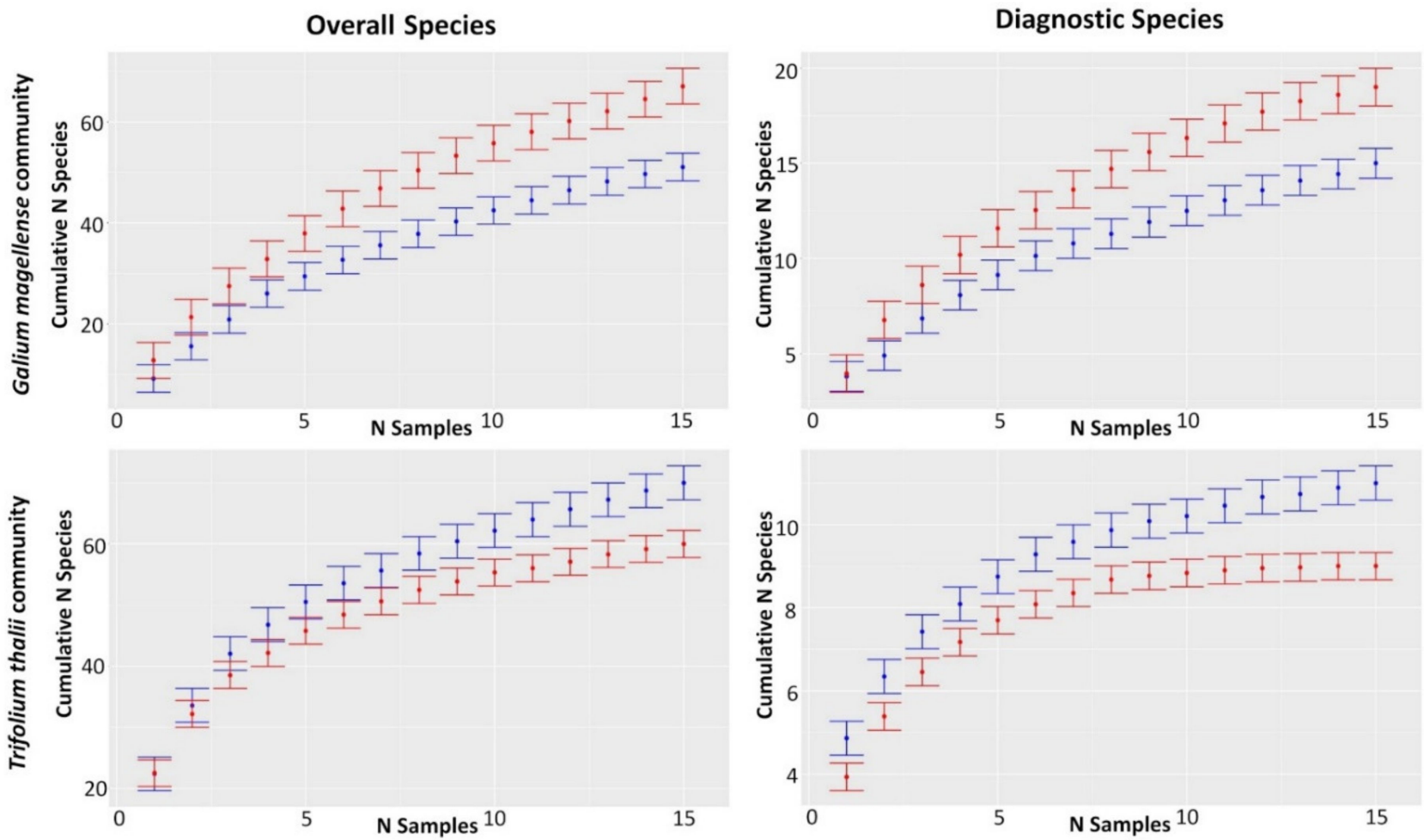

Figure 3. Plot-based rarefaction curves of the two studied plant communities, Trifolium thalii community and Galium magellense community, performed in the two time steps (blue: T1: 2001 and 2003; and red: T2: 2015 and 2020).

Table 3. Comparison of diversity parameters of overall species and diagnostic species between two time steps (T1 = 2001 and 2003; and T2 = 2015 and 2020) in Galium magellense community (scree) and Trifolium thalii community (snowbeds) $\mathrm{R}_{\text {MaoTao: Richness }}$ MaoTao; $\mathrm{H}_{\text {MaoTao: Shannon }}$ MaoTao; $\mathrm{S}_{\text {MaoTao: }}$ Simpson ${ }_{\text {MaoTao; }}$ and BP MaoTao: Berger-Parker MaoTao

\begin{tabular}{|c|c|c|c|c|c|c|c|c|c|c|c|c|}
\hline & \multicolumn{6}{|c|}{ Galium magellense Community (Scree) } & \multicolumn{6}{|c|}{ Trifolium thalii Community (Snowbeds) } \\
\hline & T1 & Lower & Upper & T2 & Lower & Upper & T1 & Lower & Upper & T2 & Lower & Upper \\
\hline & \multicolumn{6}{|c|}{ Overall Species } & \multicolumn{6}{|c|}{ Overall Species } \\
\hline $\mathrm{R}_{\text {MaoTao }}$ & 51 & 50.28 & 50.72 & 67 & 66.22 & 67.78 & 70 & 69.03 & 70.97 & 60 & 59.12 & 60.88 \\
\hline $\mathrm{H}_{\text {MaoTao }}$ & 3.649 & 3.574 & 3.668 & 3.916 & 3.845 & 3.931 & 3.932 & 3.888 & 3.946 & 3.814 & 3.772 & 3.828 \\
\hline $\mathrm{S}_{\text {MaoTao }}$ & 0.9676 & 0.9641 & 0.9689 & 0.9743 & 0.9714 & 0.9753 & 0.976 & 0.9745 & 0.9766 & 0.9739 & 0.9724 & 0.9745 \\
\hline \multirow[t]{2}{*}{$\mathrm{BP}_{\text {MaoTao }}$} & 0.0655 & 0.0568 & 0.08188 & 0.05565 & 0.05233 & 0.07143 & 0.04312 & 0.04226 & 0.05304 & 0.04458 & 0.04325 & 0.05484 \\
\hline & \multicolumn{6}{|c|}{ Diagnostic Species } & \multicolumn{6}{|c|}{ Diagnostic Species } \\
\hline $\mathrm{R}_{\text {MaoTao }}$ & 15 & 14.59 & 15.41 & 19 & 18.6 & 19.4 & 11 & 10.62 & 11.38 & 9 & 8.75 & 9.25 \\
\hline $\mathrm{H}_{\text {MaoTao }}$ & 2.404 & 2.292 & 2.46 & 2.709 & 2.615 & 2.75 & 2.109 & 2.033 & 2.157 & 1.921 & 1.841 & 1.975 \\
\hline $\mathrm{S}_{\text {MaoTao }}$ & 0.8885 & 0.8714 & 0.8979 & 0.9187 & 0.9059 & 0.9251 & 0.8567 & 0.8417 & 0.8663 & 0.826 & 0.8067 & 0.8392 \\
\hline $\mathrm{BP}_{\text {MaoTao }}$ & 0.1797 & 0.1559 & 0.2237 & 0.1701 & 0.1345 & 0.2081 & 0.2169 & 0.1952 & 0.256 & 0.2584 & 0.2274 & 0.3023 \\
\hline
\end{tabular}



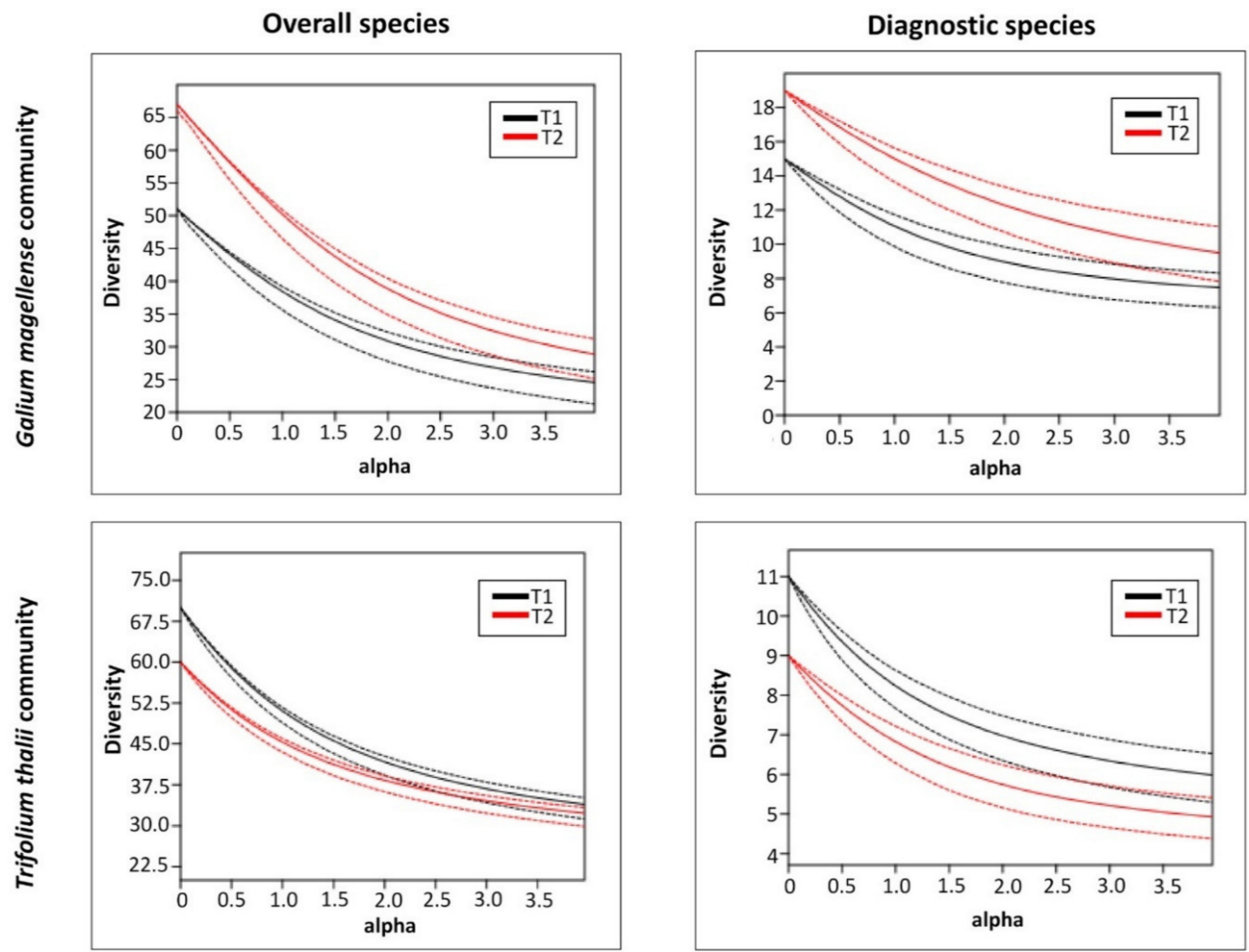

Figure 4. Renyi's diversity profiles of the two studied plant communities, Trifolium thalii community and Galium magellense community, performed on cover values for overall species and for diagnostic species in two time steps (T1: 2001 and 2003, and T2: 2015 and 2020).

\section{Discussion}

The diversity pattern on the analyzed high mountain ecosystems significantly changed over the last 20 years, with such temporal trends varying across plant communities. As shown by $\beta$-Diversity analyses, the variability of the diagnostic and the overall species pool are comparable. Furthermore, the temporal change on diversity values of the diagnostic species results were consistent with the alterations registered for the entire species pool.

Specifically, the Galium magellense community registered a sizeable gain of species richness and diversity, which could be related to an ongoing scree stabilization process caused by the increase of consolidating species, such as Androsace villosa subsp. villosa, Salix retusa, Iberis saxatilis subsp. saxatilis, and Leucopoa dimorpha (Appendix B: rank-abundance curves; and Appendix D, Table A1: complete list of recorded species and relative cover). Similar trends were observed on other European summits [101,102] and were associated with the development of incipient soils expanding inward on the scree from its base and fringes. Moreover, we also registered an increase of nitrophilous species, such as Carduus chrysacanthus, and Poa alpina subs. alpina, which is most likely related to the growing presence of the Apennine chamois (Rupicapra pyrenaica ornata Neumann, 1899). This ungulate spends the summer months on screes, providing available nitrogen in the soil with its feces [72]. However, the gain in nitrophilous species could also be due to the combined effect of faster organic matter decomposition rates due to rising temperatures $[19,103,104]$, a prolonged growing season [105], and an increased atmospheric nitrogen deposition, which become particularly severe on mountain summits [106]. 
On the other hand, the Trifolium thalii community registered a reduction of diversity values, with a moderate decline of species richness and an increase of the dominance index values. Concerning richness reduction, most of the species present in the past and registered in the recent re-survey (e.g., the diagnostic species as Phyteuma orbiculare, along with other taxa as Arabis alpina subsp. caucasica, Cerastium cerastoides, Hypericum richeri subsp. richeri, Oxytropis campestris, and Thesium parnassi) are scapose hemicryptophytes (H Scap). Among the forbs, the scapose hemicryptophytes are slightly less performant towards grazing pressure [107], and their decrease could be ascribed to the increasing grazing pressure exerted by the Apennine chamois. It is noteworthy that during summer, the Apennine chamois females and juveniles preferentially feed on snowbed grasslands [108] occupied by dense herbaceous communities [5].

The increase of dominance values in the snowbed community is supported by a cover gain of species already present in the year 2001. We also recorded an expansion of thermophilic herbaceous species well adapted to live on grasslands at lower elevation, such as Trifolium pratense subsp. semipurpureum, Carex kitaibeliana, and Taraxacum apenninum $[17,18,109]$ (Appendix C: rank-abundance curves; and Appendix D: complete list of recorded species and relative cover). Similar greening processes were observed in other alpine ecosystems and were interpreted as a climate change effect [110] and, in particular, to a winter cold stress reduction [111]. Other species expanding their cover (e.g., the diagnostic Luzula spicata subsp. bulgarica, and other species such as Trifolium thalii, Phleum rhaeticum, and Festuca violacea subsp. italica) are caespitose hemicryptophytes $(\mathrm{H}$ Caesp). The plants belonging to this life form, being capable of vegetative reproduction and spread, are well adapted to moderate-high grazing pressure [112-114], here exerted by the Apennine chamois. This wild ungulate preferentially feed on snowbed grassland with clover (e.g., Trifolium sp.) during late spring and early summer, which supplies a protein-rich diet optimal for weaning $[13,72,77,108]$.

The diversity pattern over time varied among plant communities of screes (e.g., increasing values) and snowbeds (e.g., decreasing richness and Shannon values), and the behavior of diagnostic species in both communities was consistent with the overall species pool. Our results suggest the potential of diagnostic species as a cost-effective approach for monitoring high mountain plant communities. With existing evidence supporting the role of diagnostic species for describing different ecosystems, such as forests (e.g., [51,52]), grasslands [53], and coastal dunes [54,55], these results demonstrate it can extend its field of application to include monitoring high mountain EU habitats. Such findings contribute to meet the requirement for ecosystem monitoring of regions (as high mountains) where logistic or economic restrictions make the overall periodic recording of species very difficult and time-consuming to undertake.

The re-visitation of historical vegetation plots, and the possibility of frequent monitoring based on diagnostic species, can provide updated species abundance and distribution patterns and support optimized conservation actions. Monitoring research could help to prioritize in situ measures for protecting and assuring natural environmental conditions, as well as to indicate the taxa in need of immediate ex situ conservation actions (e.g., germination test of the seeds stored in the MPP bank and species bedding and planting on alpine botanical gardens).

\section{Conclusions}

The present study, implemented by a re-visitation approach, revealed a significant change in diversity of the high mountain vegetation of the Maiella National Park over the last 20 years. In particular, it showed two opposite trends of variation in the two plant communities analyzed. Regarding the Galium magellense community growing on screes, the diversity values and species richness have grown. While, in the Trifolium thalii community of snowbeds, we found a reduction of diversity values with a moderate decline of species richness. 
These changes could be associated with two important factors: firstly, land use change, due to increase of grazing pressure of Apennine chamois introduced at the beginning of 1991 in the Park, which determined a rise of nitrophilous species in scree community and an increase of grasses (H Caesp) at the expense of forbs (H Scap) in snowbeds; and secondly, climate change, which encouraged a general expansion of thermophilous species.

Moreover, our study highlighted the role of diagnostic species in the monitoring of high mountain vegetation over time. In fact, despite the two opposite processes ongoing on the two plant communities studied, the pool of diagnostic species followed the same trend of variation of overall species pools in both communities.

Our results could support the implementation of monitoring protocols under the HD. The Habitats Directive obligates European countries to a six year reporting period and recommends an estimation of short-term trends over two reporting cycles (i.e., 12 years) and long-term trends over four reporting cycles (i.e., 24 years). Our results could help to optimize monitoring efforts by, for instance, alternating two different field collection campaigns: a) exhaustive measurements registering overall species (every 12 years) and b) partial measurements registering only diagnostics species (every 12 years). In the case of permanent plots or re-visitation sampling design, we could divide the plots into two groups and, in the first six years, register the entire pool of species in one group and the diagnostics in the second group, and then rotate, over the subsequent data collection cycles, the groups in which overall species and diagnostics are measured. Further studies conducted to better investigate the role of diagnostic species on long-term ecological monitoring over time would be beneficial.

Our study responds to the need for further monitoring studies that are able to depict vegetation dynamics occurring in remote and low-accessibility areas. The adopted re-visitation approach, based on historical plots stored in a georeferenced database, could help to reduce the gap on ecological data time series, and the results can be collated with those derived from existing permanent observation networks (e.g., LTER and GLORIA). Considering that historical vegetation plots and vegetation databases are widely available in many European countries, this adopted re-visitation study has the potential for application to other remote areas and EU habitat types in Italy and Europe at scales ranging from local to regional. The proposed monitoring approach, using historical vegetation data, can provide data over long periods of time on the abundance and distribution of species of conservation interest to be cultivated ex situ and conserved in seed banks.

Author Contributions: Conceptualization, M.V., A.S., and M.L.C.; methodology, M.V., M.D.F., A.S., and M.L.C.; software, M.V., M.D.F., and M.L.C.; validation, M.V., M.D.F., A.S., and M.L.C.; formal analysis M.V., M.D.F., and M.L.C.; investigation M.V., V.D.C., L.A.S., A.S., M.D.F., L.D.M., and M.L.C.; resources, A.S., L.D.M., and M.L.C.; data curation, M.V., V.D.C., and L.A.S.; writing-original draft preparation, M.V, M.D.F., A.S, and M.L.C.; writing-review and editing, M.V., V.D.C., L.A.S., A.S., M.D.F., L.D.M., and M.L.C.; supervision, A.S., and M.L.C. All authors have read and agreed to the published version of the manuscript.

Funding: This research was partially funded by the project MEDIALPS, EU project no. EVK2-CT2000-00056, Earth System Sciences Program of the Austrian Academy of Sciences.

Institutional Review Board Statement: Not applicable.

Informed Consent Statement: Not applicable.

Data Availability Statement: Part of the data is available from European Vegetation Archive; http:/ / euroveg.org/eva-database; (accessed on 7 April 2021).

Acknowledgments: We acknowledge the Maiella National Park staff and the Maiella Seed Bank for their essential logistic and technical support during the field campaigns.

Conflicts of Interest: The authors declare no conflict of interest. 


\section{Appendix A}

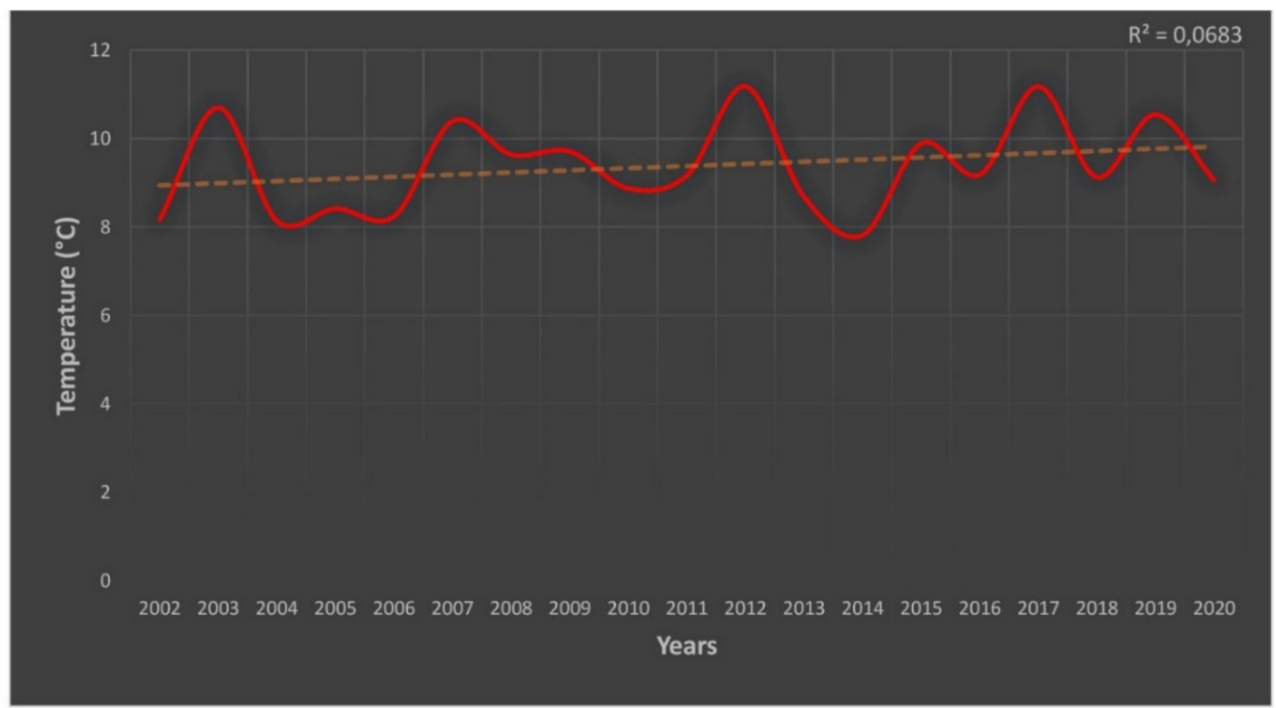

Figure A1. Mean summer (June-August) soil temperatures $\left({ }^{\circ} \mathrm{C}\right)$ of the Maiella summits for the period 2002-2020. Performed by temperature data recorded by data-logger in the three GLORIA summits of Maiella massif (Femmina Morta Mount, $2405 \mathrm{~m}$ a.s.l; Macellaro Mount, $2635 \mathrm{~m}$ a.s.l; and Mammoccio Mount, 2727 m a.s.l).

\section{Appendix B}

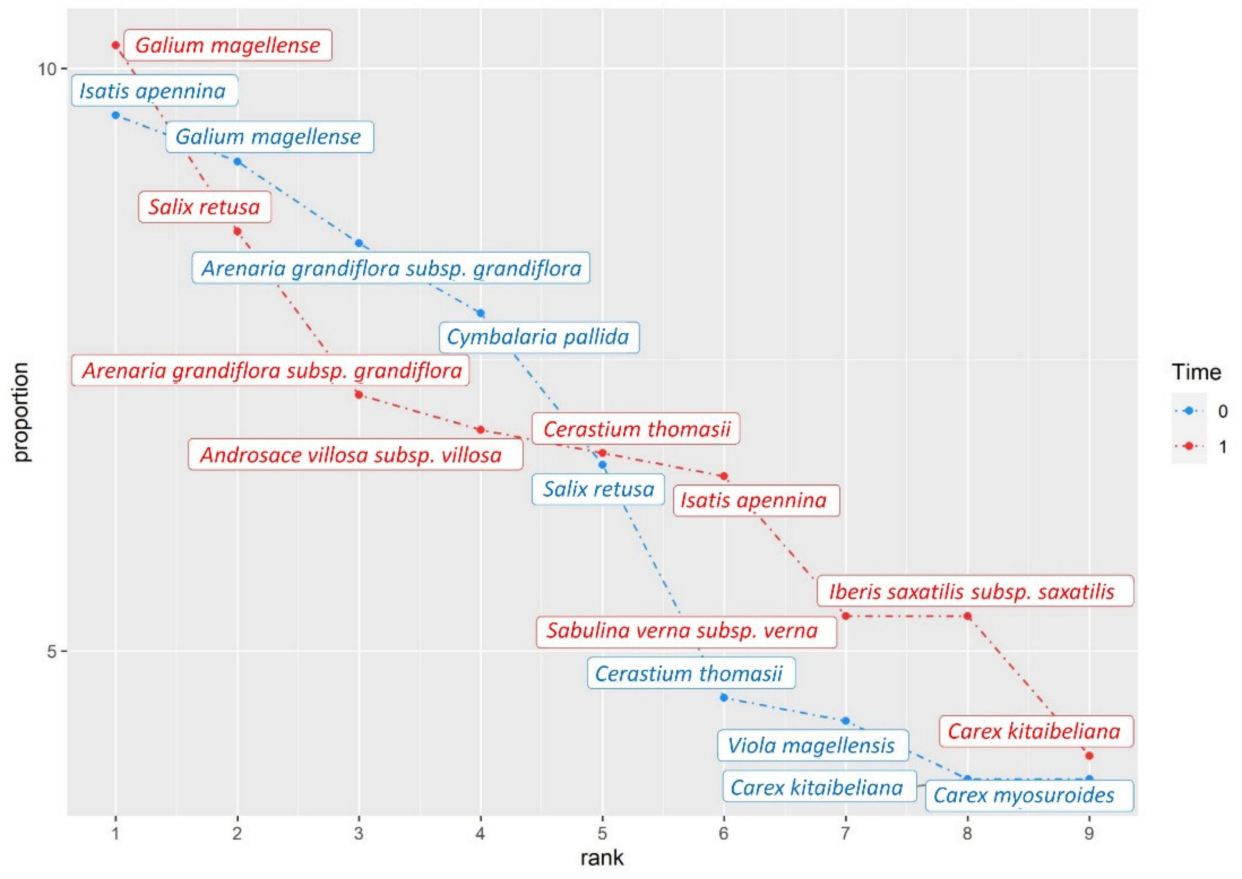

Figure A2. Rank-abundance graphics of the two plant communities analyzed, performed for overall species pool on Galium magellense community. 


\section{Appendix C}

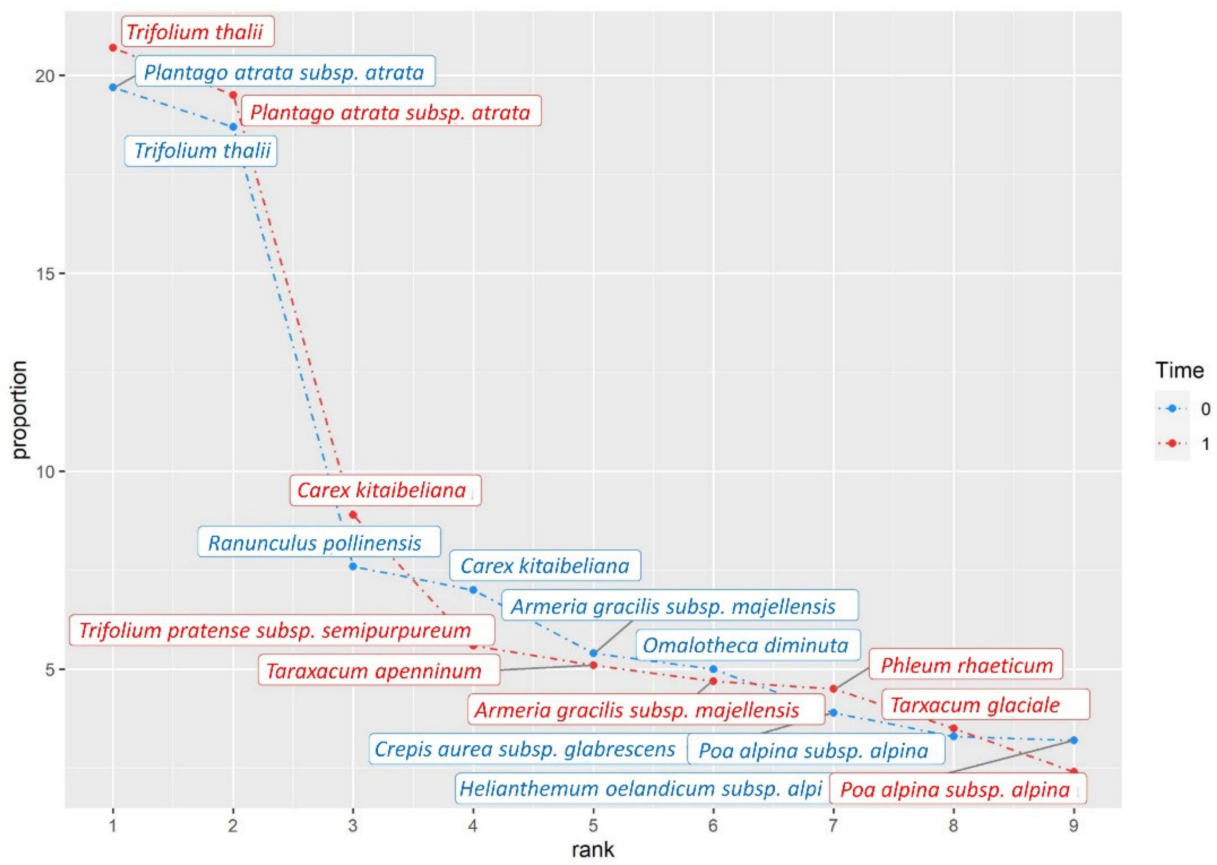

Figure A3. Rank-abundance graphics of the two plant communities analyzed, performed for overall species pool on Trifolium thalii community.

\section{Appendix D}

Table A1. List of the recorded species in the analyzed plant communities. For each species the life growth form (LGr), the taxonomic family (Family), and the mean cover in the compared time steps (T1: 2003-2005; T2: 2015-2020) are reported.

\begin{tabular}{|c|c|c|c|c|}
\hline TAXON & LGr & Family & $\%$ Cover T1 & $\%$ Cover T2 \\
\hline & \multicolumn{4}{|c|}{ Galium magellense Community(Screes) } \\
\hline *d Achillea barrelieri subsp. barrelieri & H scap & Asteraceae & 0 & 0.13 \\
\hline *Alyssum cuneifolium & $\mathrm{CH}$ suffr & Brassicaceae & 2.03 & 0.93 \\
\hline Androsace villosa subsp. villosa & $\mathrm{CH}$ rept & Primulaceae & 2.23 & 4.2 \\
\hline * Androsace vitaliana subsp. praetutiana & $\mathrm{CH}$ suffr & Primulaceae & 1.4 & 0.23 \\
\hline Anthemis cretica & H scap & Asteraceae & 0 & 0.23 \\
\hline Anthyllis vulneraria subsp. pulchella & H caesp & Fabaceae & 2 & 1.2 \\
\hline Arabis alpina subsp. caucasica & H scap & Brassicaceae & 0.63 & 0.1 \\
\hline *d Arenaria bertolonii & $\mathrm{CH}$ suffr & Caryophyllaceae & 0.2 & 0.07 \\
\hline Arenaria grandiflora subsp. grandiflora & $\mathrm{CH}$ suffr & Caryophyllaceae & 5.4 & 4.37 \\
\hline * Armeria gracilis subsp. majellensis & $\mathrm{H}$ ros & Plumbaginaceae & 0 & 0.2 \\
\hline Aster alpinus subsp. alpinus & H scap & Asteraceae & 0.2 & 0.2 \\
\hline Bistorta vivipara & G rhiz & Polygonaceae & 0.03 & 0.2 \\
\hline${ }^{\mathrm{d}}$ Campanula cochleariifolia & H scap & Campanulaceae & 0.2 & 1.04 \\
\hline Campanula scheuchzeri subsp. scheuchzeri & H scap & Campanulaceae & 1 & 0 \\
\hline${ }^{\mathrm{d}}$ Carduus chrysacanthus & H scap & Asteraceae & 0 & 1 \\
\hline Carex kitaibeliana & H caesp & Cyperaceae & 2.5 & 2.5 \\
\hline Carex myosuroides & H caesp & Cyperaceae & 2.5 & 2.5 \\
\hline * Cerastium thomasii & $\mathrm{CH}$ suffr & Caryophyllaceae & 2.9 & 4.07 \\
\hline$* d$ Cerastium tomentosum & $\mathrm{CH}$ suffr & Caryophyllaceae & 0.03 & 0.2 \\
\hline * Crepis magellensis & $\mathrm{H}$ ros & Asteraceae & 0 & 0.2 \\
\hline${ }^{\mathrm{d}}$ Crepis pygmaea & G rhiz & Asteraceae & 0.23 & 0.23 \\
\hline *d Cymbalaria pallida & H scap & Plantaginaceae & 5 & 1.2 \\
\hline * Cynoglossum magellense & $\mathrm{CH}$ suffr & Boraginaceae & 0 & 0.2 \\
\hline dDoronicum columnae & Grhiz & Asteraceae & 1 & 0.2 \\
\hline
\end{tabular}


Table A1. Cont.

\begin{tabular}{|c|c|c|c|c|}
\hline TAXON & LGr & Family & $\%$ Cover T1 & $\%$ Cover T2 \\
\hline & \multicolumn{4}{|c|}{ Galium magellense Community(Screes) } \\
\hline Draba aizoides subsp. aizoides & $\mathrm{H}$ ros & Brassicaceae & 1 & 1 \\
\hline Edraianthus graminifolius subsp. graminifolius & $\mathrm{CH}$ suffr & Campanulaceae & 1 & 1.03 \\
\hline Erigeron epiroticus & H scap & Asteraceae & 0 & 0.03 \\
\hline Euphrasia liburnica & T scap & Orobanchaceae & 0 & 0.2 \\
\hline Festuca alfrediana & H caesp & Poaceae & 0 & 0.03 \\
\hline * Festuca violacea subsp. italica & H caesp & Poaceae & 0 & 1.03 \\
\hline *d Galium magellense & H scap & Rubiaceae & 5.8 & 6.2 \\
\hline Getiana orbicularis & $\mathrm{H}$ ros & Gentianaceae & 0.03 & 0.03 \\
\hline Helianthemum oelandicum subsp. alpestre & $\mathrm{CH}$ suffr & Cistaceae & 0 & 0.2 \\
\hline * Helictochloa praetutiana subsp. praetutiana & H caesp & Poaceae & 0 & 0.07 \\
\hline Iberis saxatilis subsp. saxatilis & $\mathrm{CH}$ suffr & Brassicaceae & 2.4 & 3.2 \\
\hline $\mathrm{d}_{\text {Isatis apennina }}$ & Grhiz & Brassicaceae & 6.1 & 3.93 \\
\hline Leontopodium nivale & H scap & Asteraceae & 1.03 & 0.23 \\
\hline $\mathrm{d}_{\text {Leucopoa dimorpha }}$ & H caesp & Poaceae & 0.2 & 1.03 \\
\hline Linaria alpina & H scap & Plantaginaceae & 0.07 & 0.31 \\
\hline * Linaria purpurea & H scap & Plantaginaceae & 0 & 0.03 \\
\hline Sabulina verna subsp. verna & $\mathrm{CH}$ suffr & Caryophyllaceae & 1.43 & 3.23 \\
\hline * Myosotis graui & H scap & Boraginaceae & 0.23 & 0.5 \\
\hline *d Noccaea stylosa & $\mathrm{CH}$ suffr & Brassicaceae & 0.2 & 0.07 \\
\hline d Papaver alpinum subsp. alpinum & H scap & Papaveraceae & 0.53 & 0.37 \\
\hline * Pedicularis elegans & $\mathrm{H}$ ros & Orobanchaceae & 0.03 & 0.2 \\
\hline Phyteuma orbiculare & H scap & Campanulaceae & 0.2 & 0.03 \\
\hline Poa alpina subsp. alpina & H caesp & Poaceae & 0.7 & 1.5 \\
\hline Poa molinerii & H caesp & Poaceae & 0.03 & 0.2 \\
\hline Potentilla crantzii & H scap & Rosaceae & 0.2 & 0.03 \\
\hline Pulsatilla alpina subsp. millefoliata & H scap & Ranunculaceae & 0 & 0.23 \\
\hline $\mathrm{d}_{\text {Ranunculus brevifolius }}$ & G rhiz & Ranunculaceae & 0 & 0.03 \\
\hline Ranunculus seguieri subsp. seguieri & H scap & Ranunculaceae & 0.03 & 0.03 \\
\hline Rumex nebroides & H scap & Polygonaceae & 0.2 & 0.03 \\
\hline Salix retusa & $\mathrm{CH}$ frut & Salicaceae & 4.17 & 5.2 \\
\hline * Saxifraga exarata subsp. ampullacea & H scap & Saxifragaceae & 0.03 & 0.07 \\
\hline Saxifraga glabella & $\mathrm{CH}$ pulv & Saxifragaceae & 0.2 & 0 \\
\hline *d Saxifraga oppositifolia subsp. speciosa & $\mathrm{CH}$ pulv & Saxifragaceae & 0.43 & 0.63 \\
\hline *d Scorzoneroides montana subsp. breviscapa & $\mathrm{H}$ ros & Asteraceae & 0.43 & 0.17 \\
\hline $\mathrm{d}$ Sedum atratum & T scap & Crassulaceae & 0.03 & 0.07 \\
\hline Senecio squalidus subsp. rupestris & H bienn & Asteraceae & 0.8 & 0.6 \\
\hline Silene acaulis subsp. bryoides & $\mathrm{CH}$ pulv & Caryophyllaceae & 0.4 & 1.2 \\
\hline * Taraxacum apenninum & $\mathrm{H}$ ros & Asteraceae & 0 & 0.2 \\
\hline Thymus praecox subsp. polytrichus & $\mathrm{CH}$ rept & Lamiaceae & 0 & 0.23 \\
\hline * Trifolium pratense subsp. semipurpureum & H scap & Fabaceae & 0 & 0.2 \\
\hline Trinia dalechampii & H scap & Apiaceae & 1.23 & 0.23 \\
\hline Valeriana montana & H scap & Caprifoliaceae & 1 & 0.23 \\
\hline Valeriana saliunca & H scap & Caprifoliaceae & 0.6 & 0.63 \\
\hline * Viola eugeniae subsp. eugeniae & H scap & Violaceae & 0.3 & 0 \\
\hline *d Viola magellensis & H scap & Violaceae & 2.8 & 0.47 \\
\hline \multirow[t]{2}{*}{ Ziziphora granatensis subsp. alpina } & $\mathrm{CH}$ suffr & Lamiaceae & 0 & 0.03 \\
\hline & \multicolumn{4}{|c|}{ Trifolium thalii community (Snowbeds) } \\
\hline * Achillea barrelieri subsp. barrelieri & H scap & Asteraceae & 0.33 & 0.1 \\
\hline Anthyllis vulneraria subsp. pulchella & H caesp & Fabaceae & 0.6 & 2.97 \\
\hline Arabis alpina subsp. caucasica & H scap & Brassicaceae & 0.03 & 0 \\
\hline Arabis surculosa & H scap & Brassicaceae & 0.87 & 0.5 \\
\hline Arenaria grandiflora subsp. grandiflora & $\mathrm{CH}$ suffr & Caryophyllaceae & 0.03 & 0.03 \\
\hline * Armeria gracilis subsp. majellensis & $\mathrm{H}$ ros & Plumbaginaceae & 8.57 & 8.2 \\
\hline Astragalus depressus subsp. depressus & $\mathrm{H}$ ros & Fabaceae & 0.47 & 2.8 \\
\hline Bellidiastrum michelii & $\mathrm{H}$ ros & Asteraceae & 0 & 0.03 \\
\hline Bellis perennis & H Ros & Asteraceae & 0.1 & 0 \\
\hline
\end{tabular}


Table A1. Cont.

\begin{tabular}{|c|c|c|c|c|}
\hline TAXON & LGr & Family & $\%$ Cover T1 & $\%$ Cover T2 \\
\hline & \multicolumn{3}{|c|}{ Trifolium thalii community (Snowbeds) } & \\
\hline Bistorta vivipara & G rhiz & Polygonaceae & 0.2 & 0.03 \\
\hline Botrychium lunaria & G rhiz & Ophioglossaceae & 0.33 & 0.2 \\
\hline Campanula scheuchzeri subsp. scheuchzeri & H scap & Campanulaceae & 0.9 & 0.1 \\
\hline Carduus chrysacanthus & H scap & Asteraceae & 1.47 & 1 \\
\hline Carex kitaibeliana & H caesp & Cyperaceae & 11.23 & 15.6 \\
\hline Cerastium arvense subsp. suffruticosum & H scap & Caryophyllaceae & 0.7 & 0.23 \\
\hline Cerastium cerastoides & H scap & Caryophyllaceae & 0.03 & 0 \\
\hline * Cerastium thomasii & $\mathrm{CH}$ suffr & Caryophyllaceae & 0.7 & 0.3 \\
\hline * Cerastium tomentosum & $\mathrm{CH}$ suffr & Caryophyllaceae & 0 & 1 \\
\hline${ }^{\mathrm{d}}$ Crepis aurea subsp. glabrescens & $\mathrm{H}$ ros & Asteraceae & 6.2 & 1.47 \\
\hline Crepis pygmaea & G rhiz & Asteraceae & 0.2 & 0 \\
\hline d Draba aizoides subsp. aizoides & $\mathrm{H}$ ros & Brassicaceae & 0.47 & 0.1 \\
\hline * Edraianthus graminifolius subsp. graminifolius & $\mathrm{CH}$ suffr & Campanulaceae & 0.23 & 0 \\
\hline Erigeron epiroticus & H scap & Asteraceae & 0.1 & 0.17 \\
\hline Euphrasia liburnica & T scap & Orobanchaceae & 2.5 & 2.83 \\
\hline Euphrasia salisburgensis & T scap & Orobanchaceae & 0.07 & 0.2 \\
\hline * Festuca violacea subsp. italica & H caesp & Poaceae & 0.5 & 1.6 \\
\hline * Galium magellense & H scap & Rubiaceae & 0.3 & 0.07 \\
\hline Gentiana orbicularis & $\mathrm{H}$ ros & Gentianaceae & 0 & 0.03 \\
\hline Gentiana verna subsp. verna & $\mathrm{H}$ ros & Gentianaceae & 0.3 & 0.6 \\
\hline * Gentianella columnae & $\mathrm{H}$ bienn & Gentianaceae & 0 & 0.03 \\
\hline${ }^{\mathrm{d}}$ Helianthemum oelandicum subsp. alpestre & $\mathrm{CH}$ suffr & Cistaceae & 5.07 & 1.24 \\
\hline * Helictochloa praetutiana subsp. praetutiana & H caesp & Poaceae & 0.23 & 1.3 \\
\hline Herniaria glabra subsp. nebrodensis & T scap & Caryophyllaceae & 1.27 & 0 \\
\hline Hypericum richeri subsp. richeri & H scap & Hypericaceae & 0.2 & 0 \\
\hline * Leucopoa dimorpha & H caesp & Poaceae & 0.2 & 0 \\
\hline${ }^{\mathrm{d}}$ Luzula spicata subsp. bulgarica & H caesp & Juncaceae & 0.43 & 1.07 \\
\hline Sabulina verna subsp. verna & $\mathrm{CH}$ suffr & Caryophyllaceae & 2.07 & 1.23 \\
\hline * Myosotis graui & H scap & Boraginaceae & 0.13 & 0.07 \\
\hline * Noccaea stylosa & $\mathrm{CH}$ suffr & Brassicaceae & 0.27 & 0.01 \\
\hline Omalotheca diminuta & H scap & Asteraceae & 7.97 & 2.7 \\
\hline Oreojuncus monanthos & G rhiz & Juncaceae & 0.03 & 0.2 \\
\hline Oxytropis campestris & H scap & Fabaceae & 0.03 & 0 \\
\hline * Pedicularis elegans & $\mathrm{H}$ ros & Orobanchaceae & 0.03 & 0.1 \\
\hline Phleum rhaeticum & H caesp & Poaceae & 3.37 & 7.93 \\
\hline d Phyteuma orbiculare & H scap & Campanulaceae & 0.23 & 0 \\
\hline Pilosella lactucella subsp. nana & $\mathrm{H}$ ros & Asteraceae & 1.23 & 0.5 \\
\hline d Plantago atrata subsp. atrata & $\mathrm{H}$ ros & Plantaginaceae & 31.57 & 34.03 \\
\hline Poa alpina subsp. alpina & H caesp & Poaceae & 5.33 & 4.23 \\
\hline d Polygala alpestris subsp. angelisii & H scap & Polygonaceae & 0.03 & 0.07 \\
\hline Potentilla crantzii & H scap & Rosaceae & 0.73 & 3.93 \\
\hline d Pulsatilla alpina subsp. millefoliata & H scap & Ranunculaceae & 0.2 & 0.07 \\
\hline Ranunculus brevifolius & G rhiz & Ranunculaceae & 0.23 & 0.03 \\
\hline *d Ranunculus pollinensis & H scap & Ranunculaceae & 12.1 & 3.63 \\
\hline Rumex nebroides & H scap & Polygonaceae & 0.43 & 0.2 \\
\hline $\mathrm{d}$ Sagina glabra & H caesp & Caryophyllaceae & 0.7 & 0 \\
\hline Salix retusa & $\mathrm{CH}$ frut & Salicaceae & 0.2 & 3.53 \\
\hline Saxifraga adscendens subsp. adscendens & H bienn & Saxifragaceae & 0 & 0.07 \\
\hline Saxifraga paniculata & $\mathrm{H}$ ros & Saxifragaceae & 0.03 & 0 \\
\hline * Scorzoneroides montana subsp. breviscapa & $\mathrm{H}$ ros & Asteraceae & 0.83 & 0.4 \\
\hline Sedum acre & $\mathrm{CH}$ succ & Crassulaceae & 0.47 & 0.6 \\
\hline Sedum atratum & T scap & Crassulaceae & 0.17 & 0.15 \\
\hline Senecio squalidus subsp. rupestris & $\mathrm{H}$ bienn & Asteraceae & 0.03 & 1.07 \\
\hline Sibbaldia procumbens & H scap & Rosaceae & 0.03 & 0 \\
\hline Silene acaulis subsp. bryoides & $\mathrm{CH}$ pulv & Caryophyllaceae & 0.63 & 1.5 \\
\hline *d Taraxacum apenninum & $\mathrm{H}$ ros & Asteraceae & 1.93 & 8.9 \\
\hline * Taraxacum glaciale & $\mathrm{H}$ ros & Asteraceae & 4 & 6.13 \\
\hline
\end{tabular}


Table A1. Cont.

\begin{tabular}{lllcc}
\hline \multicolumn{1}{c}{ TAXON } & \multicolumn{1}{c}{ LGr } & \multicolumn{1}{c}{ Family } & \% Cover T1 & \% Cover T2 \\
\hline & Trifolium thalii & community (Snowbeds) & & \\
\hline Thesium parnassi & H scap & Thesiaceae & 0.23 & 0 \\
Thymus praecox subsp. polytrichus & CH rept & Lamiaceae & 2.7 & 0.43 \\
Trifolium noricum subsp. praetutianum & H caesp & Fabaceae & 0.2 & 1 \\
* Trifolium pratense subsp. semipurpureum & H scap & Fabaceae & 4.47 & 9.7 \\
Trifolium thalii & H caesp & Fabaceae & 29.97 & 36.07 \\
Trinia dalechampii & H scap & Apiaceae & 0.27 & 0.07 \\
* Viola eugeniae subsp. eugeniae & H scap & Violaceae & 1.33 & 0.27 \\
Ziziphora granatensis subsp. alpina & CH suffr & Lamiaceae & 0.9 & 1.9 \\
\hline
\end{tabular}

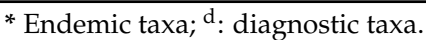

\section{References}

1. Winkler, M.; Lamprecht, A.; Steinbauer, K.; Hülber, K.; Theurillat, J.P.; Breiner, F.; Choler, P.; Ertl, S.; Gutiérrez Girón, A.; Rossi, G.; et al. The rich sides of mountain summits-A pan-European view on aspect preferences of alpine plants. J. Biogeogr. 2016, 43, 2261-2273. [CrossRef]

2. Myers, N.; Mittermeler, R.A.; Mittermeler, C.G.; Da Fonseca, G.A.B.; Kent, J. Biodiversity hotspots for conservation priorities. Nature 2000, 403, 853-858. [CrossRef] [PubMed]

3. Pauli, H.; Gottfried, M.; Dirnböck, T.; Dullinger, S.; Grabherr, G. Assessing the Long-Term Dynamics of Endemic Plants at Summit Habitats. Mediterr.-Type Ecosyst. 2003, 167, 195-207. [CrossRef]

4. Rogora, M.; Frate, L.; Carranza, M.L.; Freppaz, M.; Stanisci, A.; Bertani, I.; Bottarin, R.; Brambilla, A.; Canullo, R.; Carbognani, M.; et al. Assessment of climate change effects on mountain ecosystems through a cross-site analysis in the Alps and Apennines. Sci. Total Environ. 2018, 624, 1429-1442. [CrossRef]

5. Stanisci, A.; Carranza, M.L.; Pelino, G.; Chiarucci, A. Assessing the diversity pattern of cryophilous plant species in high elevation habitats. Plant Ecol. 2011, 212, 595-600. [CrossRef]

6. Van Gils, H.; Conti, F.; Ciaschetti, G.; Westinga, E. Fine resolution distribution modelling of endemics in Majella National Park, Central Italy. Plant Biosyst. 2012, 146, 276-287. [CrossRef]

7. Carlson, B.Z.; Randin, C.F.; Boulangeat, I.; Lavergne, S.; Thuiller, W.; Choler, P. Working toward integrated models of alpine plant distribution. Alp. Bot. 2013, 123, 41-53. [CrossRef] [PubMed]

8. Lamprecht, A.; Pauli, H.; Fernández Calzado, M.R.; Lorite, J.; Molero Mesa, J.; Steinbauer, K.; Winkler, M. Changes in plant diversity in a water-limited and isolated high-mountain range (Sierra Nevada, Spain). Alp. Bot. 2021, 131, 27-39. [CrossRef]

9. Grabherr, G.; Gottfried, M.; Pauli, H. Climate effects on mountain plants. Nature 1994, 369, 448. [CrossRef]

10. Väre, H.; Lampinen, R.; Humphries, C.; Williams, P. Taxonomic diversity of vascular plants in the European alpine areas. In Alpine Biodiversity in Europe; Springer: Berlin, Germany, 2003; pp. 133-148.

11. Thuiller, W.; Lavorel, S.; Araújo, M.B.; Sykes, M.T.; Prentice, I.C. Climate change threats to plant diversity in Europe. Proc. Natl. Acad. Sci. USA 2005, 102, 8245-8250. [CrossRef]

12. Gottfried, M.; Pauli, H.; Futschik, A.; Akhalkatsi, M.; Barančok, P.; Benito Alonso, J.L.; Coldea, G.; Dick, J.; Erschbamer, B.; Fernández Calzado, M.R.; et al. Continent-wide response of mountain vegetation to climate change. Nat. Clim. Chang. 2012, 2, 111-115. [CrossRef]

13. Frate, L.; Carranza, M.L.; Evangelista, A.; Stinca, A.; Schaminée, J.H.J.; Stanisci, A. Climate and land use change impacts on mediterranean high-mountain vegetation in the apennines since the 1950s. Plant Ecol. Divers. 2018, 11, 85-96. [CrossRef]

14. Erschbamer, B.; Kiebacher, T.; Mallaun, M.; Unterluggauer, P. Short-term signals of climate change along an altitudinal gradient in the South Alps. Plant Ecol. 2009, 202, 79-89. [CrossRef]

15. Pauli, H.; Gottfried, M.; Dullinger, S.; Abdaladze, O.; Akhalkatsi, M.; Alonso, J.L.B.; Coldea, G.; Dick, J.; Erschbamer, B.; Calzado, R.F.; et al. Recent plant diversity changes on Europe's mountain summits. Science 2012, 336, 353-355. [CrossRef] [PubMed]

16. Cannone, N.; Pignatti, S. Ecological responses of plant species and communities to climate warming: Upward shift or range filling processes? Clim. Chang. 2014, 123, 201-214. [CrossRef]

17. Evangelista, A.; Frate, L.; Carranza, M.L.; Attorre, F.; Pelino, G.; Stanisci, A. Changes in composition, ecology and structure of high-mountain vegetation: A re-visitation study over 42 years. AoB Plants 2016, 8, 1-11. [CrossRef] [PubMed]

18. Calabrese, V.; Carranza, M.L.; Evangelista, A.; Marchetti, M.; Stinca, A.; Stanisci, A. Long-term changes in the composition, ecology, and structure of Pinus mugo scrubs in the Apennines (Italy). Diversity 2018, 10, 70. [CrossRef]

19. Myers-Smith, I.H.; Forbes, B.C.; Wilmking, M.; Hallinger, M.; Lantz, T.; Blok, D.; Tape, K.D.; Maclas-Fauria, M.; Sass-Klaassen, U.; Lévesque, E.; et al. Shrub expansion in tundra ecosystems: Dynamics, impacts and research priorities. Environ. Res. Lett. 2011, 6, 045509. [CrossRef]

20. Matteodo, M.; Wipf, S.; Stöckli, V.; Rixen, C.; Vittoz, P. Elevation gradient of successful plant traits for colonizing alpine summits under climate change. Environ. Res. Lett. 2013, 8, 024043. [CrossRef] 
21. Jiménez-Alfaro, B.; Gavilán, R.G.; Escudero, A.; Iriondo, J.M.; Fernández-González, F. Decline of dry grassland specialists in Mediterranean high-mountain communities influenced by recent climate warming. J. Veg. Sci. 2014, 25, 1394-1404. [CrossRef]

22. Venn, S.; Pickering, C.; Green, K. Spatial and temporal functional changes in alpine summit vegetation are driven by increases in shrubs and graminoids. AoB Plants 2014, 6, plu008. [CrossRef]

23. Bjorkman, A.D.; Myers-Smith, I.H.; Elmendorf, S.C.; Normand, S.; Rüger, N.; Beck, P.S.A.; Blach-Overgaard, A.; Blok, D.; Cornelissen, J.H.C.; Forbes, B.C.; et al. Plant functional trait change across a warming tundra biome. Nature 2018, 562, 57-62. [CrossRef]

24. Petriccione, B.; Bricca, A. Thirty years of ecological research at the Gran Sasso d'Italia LTER site: Climate change in action. Nat. Conserv. 2019, 34, 9-39. [CrossRef]

25. Stanisci, A.; Acosta, A.T.R.; Carranza, M.L.; De Chiro, M.; Del Vecchio, S.; Di Martino, L.; Frattaroli, A.R.; Fusco, S.; Izzi, C.F.; Pirone, G. EU habitats monitoring along the coastal dunes of the LTER sites of Abruzzo and Molise (Italy). Plant Sociol. 2014, 51, $51-56$.

26. Kullman, L. Alpine flora dynamics-A critical review of responses to climate change in the Swedish Scandes since the early 1950 s. Nord. J. Bot. 2010, 28, 398-408. [CrossRef]

27. Gaston, K.J.; Jackson, S.F.; Nagy, A.; Cantú-Salazar, L.; Johnson, M. Protected areas in Europe: Principle and practice. Ann. N. Y. Acad. Sci. 2008, 1134, 97-119. [CrossRef]

28. Louette, G.; Adriaens, D.; Paelinckx, D.; Hoffmann, M. Implementing the habitats directive: How science can support decision making. J. Nat. Conserv. 2015, 23, 27-34. [CrossRef]

29. Council Directive 92/43/EEC of 21 May 1992 on the conservation of natural habitats and of wild fauna and flora. Off. J. Eur. Union 1992, 206, 7.

30. Janssen, J.A.M.; Rodwell, J.S.; Criado, M.G.; Gubbay, S.; Haynes, T.; Nieto, A.; Sanders, N.; Calix, M. European Red List of Habitats; Publications Office of the European Union: Luxembourg, 2016; ISBN 9279615882.

31. Gigante, D.; Acosta, A.T.R.; Agrillo, E.; Armiraglio, S.; Assini, S.; Attorre, F.; Bagella, S.; Buffa, G.; Casella, L.; Giancola, C.; et al. Habitat conservation in Italy: The state of the art in the light of the first European Red List of Terrestrial and Freshwater Habitats. Rend. Lincei 2018, 29, 251-265. [CrossRef]

32. Pauli, H.; Gottfried, M.; Reiter, K.; Klettner, C.; Grabherr, G. Signals of range expansions and contractions of vascular plants in the high Alps: Observations (1994-2004) at the GLORIA *master site Schrankogel, Tyrol, Austria. Glob. Chang. Biol. 2007, 13, 147-156. [CrossRef]

33. Păcurar, F.; Rotar, I.; Reif, A.; Vidican, R.; Stoian, V.; Gärtner, S.M.; Allen, R.B. Impact of climate on vegetation change in a mountain grassland-Succession and fluctuation. Not. Bot. Horti Agrobot. Cluj-Napoca 2014, 42, 347-356. [CrossRef]

34. Stöckli, V.; Wipf, S.; Nilsson, C.; Rixen, C. Using historical plant surveys to track biodiversity on mountain summits. Plant Ecol. Divers. 2011, 4, 415-425. [CrossRef]

35. Elmendorf, S.C.; Henry, G.H.R.; Hollister, R.D.; Björk, R.G.; Boulanger-Lapointe, N.; Cooper, E.J.; Cornelissen, J.H.C.; Day, T.A.; Dorrepaal, E.; Elumeeva, T.G. Plot-scale evidence of tundra vegetation change and links to recent summer warming. Nat. Clim. Chang. 2012, 2, 453-457. [CrossRef]

36. Steinbauer, M.J.; Grytnes, J.-A.; Jurasinski, G.; Kulonen, A.; Lenoir, J.; Pauli, H.; Rixen, C.; Winkler, M.; Barni, M.B.-D.E.; Bjorkman, A.D.; et al. Mountain Summits Is Linked to Warming. Nature 2018, 556, 231-234. [CrossRef] [PubMed]

37. Pauli, H.; Gottfried, M.; Lamprecht, A.; Niessner, S.; Rumpf, S.; Winkler, M.; Steinbauer, K.; Grabherr, G. The GLORIA Field Manual; Global Observation Research Initiative in Alpine Environments: Vienna, Austria, 2015. [CrossRef]

38. Bürli, S.; Theurillat, J.P.; Winkler, M.; Lamprecht, A.; Pauli, H.; Rixen, C.; Steinbauer, K.; Wipf, S.; Abdaladze, O.; Andrews, C.; et al. A common soil temperature threshold for the upper limit of alpine grasslands in European mountains. Alp. Bot. 2021, 131, 41-52. [CrossRef]

39. Haase, P.; Tonkin, J.D.; Stoll, S.; Burkhard, B.; Frenzel, M.; Geijzendorffer, I.R.; Häuser, C.; Klotz, S.; Kühn, I.; McDowell, W.H.; et al. The next generation of site-based long-term ecological monitoring: Linking essential biodiversity variables and ecosystem integrity. Sci. Total Environ. 2018, 613-614, 1376-1384. [CrossRef] [PubMed]

40. Hoffmann, A.; Penner, J.; Vohland, K.; Cramer, W.; Doubleday, R.; Henle, K.; Kõljalg, U.; Kühn, I.; Kunin, W.E.; Negro, J.J.; et al. Improved access to integrated biodiversity data for science, practice, and policy-The European Biodiversity Observation Network (EU BON). Nat. Conserv. 2014, 6, 49-65. [CrossRef]

41. Michener, W.K. Ecological data sharing. Ecol. Inform. 2015, 29, 33-44. [CrossRef]

42. Magurran, A.E.; Baillie, S.R.; Buckland, S.T.; Dick, J.M.P.; Elston, D.A.; Scott, E.M.; Smith, R.I.; Somerfield, P.J.; Watt, A.D. Long-term datasets in biodiversity research and monitoring: Assessing change in ecological communities through time. Trends Ecol. Evol. 2010, 25, 574-582. [CrossRef]

43. Chytrý, M.; Hennekens, S.M.; Jiménez-Alfaro, B.; Knollová, I.; Dengler, J.; Jansen, F.; Landucci, F.; Schaminée, J.H.J.; Aćić, S.; Agrillo, E.; et al. European Vegetation Archive (EVA): An integrated database of European vegetation plots. Appl. Veg. Sci. 2016, 19, 173-180. [CrossRef]

44. Schaminée, J.H.J.; Janssen, J.A.M.; Hennekens, S.M.; Ozinga, W.A. Large vegetation databases and information systems: New instruments for ecological research, nature conservation, and policy making. Plant Biosyst. 2011, 145, 85-90. [CrossRef]

45. Franklin, J.; Serra-Diaz, J.M.; Syphard, A.D.; Regan, H.M. Big data for forecasting the impacts of global change on plant communities. Glob. Ecol. Biogeogr. 2017, 26, 6-17. [CrossRef] 
46. Vittoz, P.; Bayfield, N.; Brooker, R.; Elston, D.A.; Duff, E.I.; Theurillat, J.P.; Guisan, A. Reproducibility of species lists, visual cover estimates and frequency methods for recording high-mountain vegetation. J. Veg. Sci. 2010, 21, 1035-1047. [CrossRef]

47. Testolin, R.; Attorre, F.; Borchardt, P.; Brand, R.F.; Bruelheide, H.; Chytrý, M.; De Sanctis, M.; Dolezal, J.; Finckh, M.; Haider, S.; et al. Global patterns and drivers of alpine plant species richness. Glob. Ecol. Biogeogr. 2021, 30, 1218-1231. [CrossRef]

48. Zamora, R.; Pérez-Luque, A.J.; Bonet, F.J. Monitoring global change in high mountains. In High Mountain Conservation in a Changing World; Advances in Global Change Research; Springer: Cham, Switzerland, 2017; Volume 62, pp. $385-413$.

49. Rocchini, D.; Andreini Butini, S.; Chiarucci, A. Maximizing plant species inventory efficiency by means of remotely sensed spectral distances. Glob. Ecol. Biogeogr. 2005, 14, 431-437. [CrossRef]

50. Verrall, B.; Pickering, C.M. Alpine vegetation in the context of climate change: A global review of past research and future directions. Sci. Total Environ. 2020, 748, 141344. [CrossRef] [PubMed]

51. Carranza, M.L.; Frate, L.; Paura, B. Structure, ecology and plant richness patterns in fragmented beech forests. Plant Ecol. Divers. 2012, 5, 541-551. [CrossRef]

52. Kovač, M.; Kutnar, L.; Hladnik, D. Assessing biodiversity and conservation status of the Natura 2000 forest habitat types: Tools for designated forestlands stewardship. For. Ecol. Manag. 2016, 359, 256-267. [CrossRef]

53. Nicod, C.; Leys, B.; Ferrez, Y.; Manneville, V.; Mouly, A.; Greffier, B.; Hennequin, C.; Bouton, Y.; Prévost-Bouré, N.C.; Gillet, F. Towards the assessment of biodiversity and management practices in mountain pastures using diagnostic species? Ecol. Indic. 2019, 107, 1-21. [CrossRef]

54. Santoro, R.; Carboni, M.; Carranza, M.L.; Acosta, A.T.R. Focal species diversity patterns can provide diagnostic information on plant invasions. J. Nat. Conserv. 2012, 20, 85-91. [CrossRef]

55. Angiolini, C.; Bonari, G.; Landi, M. Focal plant species and soil factors in Mediterranean coastal dunes: An undisclosed liaison? Estuar. Coast. Shelf Sci. 2018, 211, 248-258. [CrossRef]

56. Chytrý, M.; Tichý, L. Diagnostic, Constant and Dominant Species of Vegetation Classes and Alliances of the Czech. Republic: A Statistical Revision; Masaryk University Brno: Brno, Czech Republic, 2003; Volume 108, ISBN 8021032219.

57. Chiarucci, A.; Bacaro, G.; Rocchini, D. Quantifying plant species diversity in a Natura 2000 network: Old ideas and new proposals. Biol. Conserv. 2008, 141, 2608-2618. [CrossRef]

58. Körner, C. Alpine Plant Life: Functional Plant Ecology of High Mountain Ecosystems; Springer Nature: Basingstoke, UK, 2021; ISBN 3030595382.

59. Chytrý, M.; Tichý, L.; Hennekens, S.M.; Knollová, I.; Janssen, J.A.M.; Rodwell, J.S.; Peterka, T.; Marcenò, C.; Landucci, F.; Danihelka, J.; et al. EUNIS Habitat Classification: Expert system, characteristic species combinations and distribution maps of European habitats. Appl. Veg. Sci. 2020, 23, 648-675. [CrossRef]

60. Stanisci, A.; Bricca, A.; Calabrese, V.; Cutini, M.; Pauli, H.; Steinbauer, K.; Carranza, M.L. Functional composition and diversity of leaf traits in subalpine versus alpine vegetation in the Apennines. AoB Plants 2020, 12, 1-11. [CrossRef] [PubMed]

61. Lucchese, F.; Simone, M.D.E.; Tra, C.; Altitudine, F.D.; Appennino, N.; Metodi, C.; Rilevamento, D.I.; Risultati, E.; Di, A.; Caratterizzazione, U.N.A. Confronto tra flore d'altitudine nell'appennino centrale. Metodi di rilevamento, risultati e analisi di una caratterizzazione fitogeografica. Ann. Musei Civ. 2000, 14, 113-145.

62. Birot, P. Géomorphologie des Abruzzes adriatiques de Jean Demangeot; Annales de Géographie: Paris, France, 1966; Volume 75, pp. $480-482$.

63. Jaurand, E. Les Heritages Glaciaire de l'Apennin. Ph.D. Thesis, Éditions de la Sorbonne Paris, Paris, France, 1994.

64. Di Cecco, V.; Di Santo, M.; Di Musciano, M.; Manzi, A.; Di Cecco, M.; Ciaschetti, G.; Marcantonio, G.; Di Martino, L. The Majella national park: A case study for the conservation of plant biodiversity in the Italian apennines. Ital. Bot. 2020, 10, 1-24. [CrossRef]

65. Conti, F.; Ciaschetti, G.; Di Martino, L.; Bartolucci, F. An Annotated Checklist of the Vascular Flora of Majella National Park (Central Italy). Phytotaxa 2019, 412, 1-90. [CrossRef]

66. Conti, F.; Tinti, D. Data base della flora vascolare del Parco Nazionale della Majella. In Atti del Convegno "La Biodiversità Vegetale Nelle Aree Protette in Abruzzo: Studi ed Esperienze a Confronto"; Giovanni, R.S., Ed.; Ente Parco Nazionale della Majella: Pacentro, Italy, 2006; pp. 183-191.

67. Cervellini, M.; Zannini, P.; Di Musciano, M.; Fattorini, S.; Jiménez-Alfaro, B.; Rocchini, D.; Field, R.; Vetaas, O.R.; Irl, S.D.H.; Beierkuhnlein, C.; et al. A grid-based map for the biogeographical regions of Europe. Biodivers. Data J. 2020, 8, e53720. [CrossRef]

68. Blasi, C.; Di Pietro, R.; Pelino, G. The vegetation of alpine belt karst-tectonic basins in the central Apennines (Italy). Plant Biosyst. 2005, 139, 357-385. [CrossRef]

69. Dai, L.; Palombo, C.; Van Gils, H.; Rossiter, D.G.; Tognetti, R.; Luo, G. Pinus mugo Krummholz Dynamics during Concomitant Change in Pastoralism and Climate in the Central Apennines. Mt. Res. Dev. 2017, 37, 75-86. [CrossRef]

70. Palombo, C.; Chirici, G.; Marchetti, M.; Tognetti, R. Is land abandonment affecting forest dynamics at high elevation in Mediterranean mountains more than climate change? Plant Biosyst. 2013, 147, 1-11. [CrossRef]

71. Antonucci, A.; Di Domenico, G.; Gentile, D.; Artese, C. Documento Operativo sulle Corrette Procedure per L'individuazione dei Nuclei di Camoscio Oggetto di Prelievo per le Immissioni in Natura. 2010, pp. 1-16. Available online: https://www. camoscioappenninico.it/camoscioappenninico.it/sites/camoscioappenninico.it/files/docs/5.pdf (accessed on 21 July 2021).

72. Lovari, S.; Franceschi, S.; Chiatante, G.; Fattorini, L.; Fattorini, N.; Ferretti, F. Climatic changes and the fate of mountain herbivores. Clim. Chang. 2020, 162, 2319-2337. [CrossRef] 
73. Loison, A.; Toïgo, C.; Appolinaire, J.; Michallet, J. Demographic processes in colonizing populations of isard (Rupicapra pyrenaica) and ibex (Capra ibex). J. Zool. 2002, 256, 199-205. [CrossRef]

74. Biondi, E.; Blasi, C.; Burrascano, S.; Casavecchia, S.; Copiz, R.; Del Vico, E.; Galdenzi, D.; Gigante, D.; Lasen, C.; Spampinato, G.; et al. Manuale Italiano di Interpretazione degli Habitat della Direttiva 92/43/CEE; Ministero dell'Ambiente e della Tutela del Territorio e del Mare, Direzione per la Protezione della Natura: Rome, Italy, 2009; pp. 1-16.

75. European Commission. Interpretation Manual of European Union Habitats; Directorate-General for the Environment: Brussels, Belgium, 2013.

76. Evangelista, A.; Frate, L.; Stinca, A.; Carranza, M.L.; Stanisci, A. VIOLA-The vegetation database of the central Apennines: Structure, current status and usefulness for monitoring Annex i EU habitats (92/43/EEC). Plant Sociol. 2016, 53, 47-58. [CrossRef]

77. Stanisci, A.; Evangelista, A.; Frate, L.; Stinca, A.; Carranza, M.L. VIOLA-Database of high mountain vegetation of central apennines. Phytocoenologia 2016, 46, 231-232. [CrossRef]

78. Pelino, G.; Carranza, M.L.; Stanisci, A. Specie rare nelle unità ambientali del piano alpino del Parco Nazionale della Majella. Informatore Botanico Italiano 2005, 37, 288-289.

79. Braun-Blanquet, J. Pflanzensoziologie: Grundzüge der Vegetationskunde; Springer: Berlin, Germany, 2013 ; ISBN 3709140781.

80. Westhoff, V.; Van Der Maarel, E. The braun-blanquet approach. In Classification of plant communities; Springer: Berlin/Heidelberg, Germany, 1978; pp. 287-399.

81. Bartolucci, F.; Peruzzi, L.; Galasso, G.; Albano, A.; Alessandrini, A.; Ardenghi, N.M.G.; Astuti, G.; Bacchetta, G.; Ballelli, S.; Banfi, E.; et al. An updated checklist of the vascular flora native to Italy. Plant Biosyst. 2018, 152, 179-303. [CrossRef]

82. Biondi, E.; Blasi, C.; Allegrezza, M.; Anzellotti, I.; Azzella, M.M.; Carli, E.; Casavecchia, S.; Copiz, R.; Del Vico, E.; Facioni, L.; et al. Plant communities of Italy: The Vegetation Prodrome. Plant Biosyst. 2014, 148, 728-814. [CrossRef]

83. European Commission Interpretation Manual of European Union Habitats; Directorate-General for the Environment: Brussels, Belgium, 2007.

84. Raunkiaer, C. The Life Forms of Plants and Statistical Plant Geography; Oxford University Press: Oxford, UK, 1934.

85. Pignatti, S.; Guarino, R.; La Rosa, M. Flora d'Italia; Edagricole: Rome, Italy, 2017; Volume 1, ISBN 8850652429.

86. Anderson, M.J. Distance-based tests for homogeneity of multivariate dispersions. Biometrics 2006, 62, 245-253. [CrossRef] [PubMed]

87. Oksanen, A.J.; Blanchet, F.G.; Friendly, M.; Kindt, R.; Legendre, P.; Mcglinn, D.; Minchin, P.R.; Hara, R.B.O.; Simpson, G.L.; Solymos, P.; et al. Vegan Package 2020. Available online: https:/ / github.com/vegandevs/vegan (accessed on 7 February 2021).

88. Gotelli, N.J.; Colwell, R.K. Quantifying biodiversity: Procedures and pitfalls in the measurement and comparison of species richness. Ecol. Lett. 2001, 4, 379-391. [CrossRef]

89. Colwell, R.K.; Mao, C.X.; Chang, J. Interpolating, extrapolating, and comparing incidence-based species accumulation curves. Ecology 2004, 85, 2717-2727. [CrossRef]

90. Hill, M.O. Diversity and Evenness: A Unifying Notation and Its Consequences. Ecology 1973, 54, 427-432. [CrossRef]

91. Tothmeresz, B. Comparison of Different Methods for Diversity Ordering. J. Veg. Sci. 1995, 6, 283-290. [CrossRef]

92. R Core Team, R. A Language and Environment for Statistical Computing; R Foundation for Statistical Computing: Vienna, Austria, 2020. Available online: http:/ /www.r-project.org/index.html (accessed on 7 February 2021).

93. Thouverai, E.; Pavoine, S.; Tordini, E.; Rocchini, D.; Ricotta, C.; Chiarucci, A.; Bacaro, G. Rarefy Package: Rarefaction Methods 2021. Available online: https:/ / cran.r-project.org/web/packages/Rarefy/Rarefy.pdf (accessed on 10 June 2021).

94. Kindt, R.; Coe, R. Tree Diversity Analysis; World Agroforestry Centre: Nairobi, Kenya, 2005.

95. Hammer, Ø.; Harper, D.A.T.; Ryan, P.D. Past Palaeontological Statistics, Ver. 1.79. 2001. pp. 1-88. Available online: https://palaeo-electronica.org/2001_1/past/issue1_01.htm\#: \{\}:text=The \%20program\%2C\%20called\%20PAST\%20 (PAleontological,plotting\%2C\%20and\%20simple\%20phylogenetic\%20analysis (accessed on 10 June 2021).

96. Rényi, A. Some fundamental questions of information theory, MTA III Oszt. Közl. 10 251; 1960 On measures of information and entropy. In Proceedings of the Fourth Berkeley Symposium on Mathematics, Statistics and Probability, Berkeley, CA, USA, 20 June-30 July 1960; Berkeley University Press: Berkeley, CA, USA, 1970.

97. Shannon, C.E.; Weaver, W. The Mathematical Theory of Communication. In Urbana and Chicago; University of Illinois Press: Champaign, IL, USA, 1949.

98. Simpson, G.L. Measurement of diversity. Nature 1949, 163, 688. [CrossRef]

99. Berger, W.H.; Parker, F.L. Diversity of planktonic foraminifera in deep-sea sediments. Science 1970, 168, 1345-1347. [CrossRef]

100. Patil, G.P.; Taillie, C. Diversity as a concept and its measurement. J. Am. Stat. Assoc. 1982, 77, 548-561. [CrossRef]

101. Cannone, N.; Gerdol, R. Vegetation as an Ecological Indicator of Surface Instability in Rock Glaciers. Arctic, Antarct. Alp. Res. 2003, 35, 384-390. [CrossRef]

102. Rixen, C.; Wipf, S. Non-equilibrium in alpine plant assemblages: Shifts in Europe's summit floras. In High Mountain Conservation in a Changing World; Springer: Cham, Switzerland, 2017; pp. 285-303.

103. Gavazov, K.S. Dynamics of alpine plant litter decomposition in a changing climate. Plant Soil 2010, 337, 19-32. [CrossRef]

104. Gong, S.; Guo, R.; Zhang, T.; Guo, J. Warming and nitrogen addition increase litter decomposition in a temperate meadow ecosystem. PLoS ONE 2015, 10, 1-14. [CrossRef] [PubMed]

105. Chersich, S.; Rejšek, K.; Vranová, V.; Bordoni, M.; Meisina, C. Climate change impacts on the Alpine ecosystem: An overview with focus on the soil-A review. J. For. Sci. 2015, 61, 496-514. [CrossRef] 
106. Gillet, F.; Mauchamp, L.; Badot, P.M.; Mouly, A. Recent changes in mountain grasslands: A vegetation resampling study. Ecol. Evol. 2016, 6, 2333-2345. [CrossRef]

107. López-i-Gelats, F.; Rivera-Ferre, M.G.; Madruga-Andreu, C.; Bartolomé-Filella, J. Is multifunctionality the future of mountain pastoralism? Lessons from the management of semi-natural grasslands in the Pyrenees. Spanish J. Agric. Res. 2015, 13. [CrossRef]

108. Ferrari, C.; Rossi, G.; Cavani, C. Summer food habits and quality of female, kid and subadult Apennine chamois, Rupicapra pyrenaica ornata Neumann, 1899 (Artiodactyla, Bovidae). Z. Säugetierkd. 1988, 53, 170-177.

109. Cannone, N.; Sgorbati, S.; Guglielmin, M. Unexpected impacts of climate change on alpine vegetation. Front. Ecol. Environ. 2007, 5, 360-364. [CrossRef]

110. Bolton, D.K.; Coops, N.C.; Hermosilla, T.; Wulder, M.A.; White, J.C. Evidence of vegetation greening at alpine treeline ecotones: Three decades of landsat spectral trends informed by lidar-derived vertical structure. Environ. Res. Lett. 2018, 13, 84022. [CrossRef]

111. Carlson, B.Z.; Corona, M.C.; Dentant, C.; Bonet, R.; Thuiller, W.; Choler, P. Observed long-term greening of alpine vegetation-A case study in the French Alps. Environ. Res. Lett. 2017, 12, 114006. [CrossRef]

112. Evju, M.; Austrheim, G.; Halvorsen, R.; Mysterud, A. Grazing responses in herbs in relation to herbivore selectivity and plant traits in an alpine ecosystem. Oecologia 2009, 161, 77-85. [CrossRef] [PubMed]

113. Catorci, A.; Ottaviani, G.; Ballelli, S.; Cesaretti, S. Functional differentiation of central apennine grasslands under mowing and grazing disturbance regimes. Pol. J. Ecol. 2011, 59, 115-128.

114. Mayer, R.; Erschbamer, B. Long-term effects of grazing on subalpine and alpine grasslands in the Central Alps, Austria. Basic Appl. Ecol. 2017, 24, 9-18. [CrossRef] 